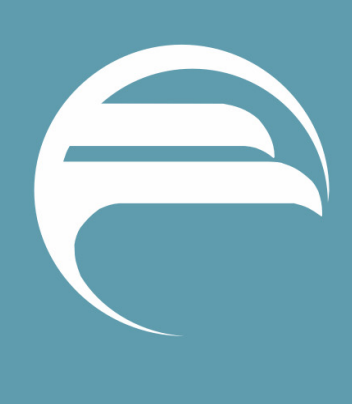

\title{
WORKING PAPER NO. 05-29 \\ POTENTIAL COMPETITIVE EFFECTS ON U.S. BANK \\ CREDIT CARD LENDING FROM THE PROPOSED BIFURCATED APPLICATION OF BASEL II
}

William W. Lang

Federal Reserve Bank of Philadelphia

Loretta J. Mester

Federal Reserve Bank of Philadelphia and

Wharton School, University of Pennsylvania

Todd A. Vermilyea

Federal Reserve Bank of Philadelphia

December 5, 2005

Research Department, Federal Reserve Bank of Philadelphia

Ten Independence Mall, Philadelphia, PA 19106-1574 • www.philadelphiafed.org/econ/index.html 


\title{
Potential Competitive Effects on U.S. Bank Credit Card Lending from the Proposed Bifurcated Application of Basel II
}

\author{
William W. Lang \\ Federal Reserve Bank of Philadelphia \\ Loretta J. Mester \\ Federal Reserve Bank of Philadelphia and \\ Wharton School, University of Pennsylvania \\ Todd A. Vermilyea \\ Federal Reserve Bank of Philadelphia
}

December 5, 2005

Correspondence to Lang at Supervision, Regulation, and Credit Department, Federal Reserve Bank of Philadelphia, Ten Independence Mall, Philadelphia, PA 19106-1574; phone: (215) 574-7225; e-mail: William.Lang@phil.frb.org. To Mester at Research Department, Federal Reserve Bank of Philadelphia, Ten Independence Mall, Philadelphia, PA 19106-1574; phone: (215) 574-3807; e-mail:

Loretta.Mester@phil.frb.org. To Vermilyea at Supervision, Regulation, and Credit Department, Federal Reserve Bank of Philadelphia, Ten Independence Mall, Philadelphia, PA 19106-1574; phone: (215) 5744125; e-mail: Todd.Vermilyea@phil.frb.org.

We thank Jim DiSalvo and Vidya Nayak for research assistance and Sally Burke for editorial assistance.

The views expressed in this paper do not necessarily represent those of the Federal Reserve Bank of Philadelphia or the Federal Reserve System. 


\section{Potential Competitive Effects on U.S. Bank Credit Card Lending from the Proposed Bifurcated Application of Basel II}

\section{Introduction and Executive Summary}

This paper analyzes the potential competitive effects of the proposed bifurcated application of Basel II capital regulations in the United States on bank credit card lending activities. ${ }^{1}$ For this purpose, we consider the Basel II regulations as stated in the June 2004 Basel Committee Framework Agreement. ${ }^{2}$ The advanced internal ratings-based (A-IRB) approach is designed to be a more risk-sensitive means of assessing minimum regulatory capital than the current Basel I-based approach. Under the A-IRB framework, the regulatory capital requirement for a bank's on-balance-sheet credit card portfolio would be a function of internal bank estimates of the probability of default (PD), loss given default (LGD), and exposure at default (EAD). In contrast, the Basel I-based approach requires the same minimum capital charge ( 8 percent) on all credit card exposures, regardless of the actual credit risk of those exposures. The Basel I-based approach has been criticized because of this "one-size-fits-all" nature. The Basel II proposal takes a significant step toward making the minimum regulatory capital requirements better reflect the risks of particular assets. Under the current proposal of U.S. banking regulators, the Basel II capital framework would result in a bifurcated capital regime: A relatively small number of large U.S. banking organizations (i.e., independent banks and bank holding companies) would use the advanced internal ratings-based (A-IRB) approach for credit risk and the advanced measurement approach (AMA) for operational risk, while other U.S. banks would continue to apply the current Basel I-based capital rules. $^{3}$

\footnotetext{
${ }^{1}$ The Basel Committee on Banking Supervision is a committee of banking supervisory authorities established in 1975 by the central bank governors of the Group of 10 countries. It comprises senior representatives of bank supervisory authorities and central banks from Belgium, Canada, France, Germany, Italy, Japan, Luxembourg, the Netherlands, Spain, Sweden, Switzerland, the United Kingdom, and the United States. The committee usually meets at the Bank for International Settlements in Basel, where its permanent Secretariat is located.

${ }^{2}$ See "International Convergence of Capital Measurement and Capital Standards: A Revised Framework," Basel Committee on Banking Supervision (June 2004).

${ }^{3}$ See the "Advance Notice of Proposed Rulemaking: Risk-Based Capital Guidelines and Implementation of New Basel Capital Accord," August 4, 2003. Under the current proposal of the U.S. banking agencies, banks with over $\$ 250$ billion in total assets or $\$ 10$ billion in on-balance-sheet foreign exposures would be required to adopt the
} 
Approximately 10 of the largest U.S. banking organizations will be required to adopt the A-IRB approach of Basel II under the current proposal of the U.S. bank regulatory agencies. ${ }^{4}$ While in principle any bank can choose to opt in if it meets the minimum regulatory standards for implementing A-IRB, it is expected that most banks will not have the necessary infrastructure in place to opt in. Thus, after Basel II's implementation in the U.S. in 2008, it is likely that most U.S. banks' regulatory capital requirements would continue to be determined under current Basel I-based rules, while the largest banks' capital ratios would be determined using the A-IRB approach.

Proposals to alter the existing capital framework raise questions as to the effect of these new rules on the competitive positions of U.S. banks that remain under the current capital regime. In the U.S., some bankers, particularly community bankers, have expressed concern that banks using A-IRB would face lower capital requirements for various products (including credit cards) and that this will place banks not using the A-IRB approach at a disadvantage. ${ }^{5,6,7}$ In addition, the new capital rules have the potential to affect the competitive position of Basel II adopters relative to nonbank rivals. This paper explores these potential competitive effects as they relate to the credit card industry.

We first examine whether the adoption of the A-IRB is likely to have an impact on the competitive position of community and regional banks. We then address the more general question of whether U.S. banks' adoption of the A-IRB would likely affect their competitive position vis-à-vis banks

A-IRB approach. Other U.S. banking organizations could opt in to the A-IRB approach if they meet regulatory standards. Outside of the U.S., banks not subject to A-IRB would be subject to either the "Foundation IRB" approach, a less advanced version of the IRB, or the "Standardized Approach," a modified version of the existing Basel I methodology of applying regulatory mandated risk weights to particular types of assets. In the U.S., neither the standardized approach nor the foundation approach will be used.

${ }^{4}$ See "Advance Notice of Proposed Rulemaking: Risk-Based Capital Guidelines and Implementation of New Basel Capital Accord," August 4, 2003.

${ }^{5}$ See “Smaller U.S. Banks Say Basel Accord Unfair,” Reuters News, June 22, 2004.

${ }^{6}$ In this study, the term "community bank" refers to a banking organization with assets of less than $\$ 1$ billion. The term "regional bank" refers to a banking organization with assets over a $\$ 1$ billion that operates in a region of the U.S. and not nationally or globally. Unless otherwise noted, the term "bank" will mean depository institution more generally.

${ }^{7}$ The agencies have indicated that they intend to propose simple modifications to the current U.S. Basel-I based capital standards designed to make the current standards more risk sensitive. In part, these modifications are 
operating under Basel I-based rules. Finally, we examine whether U.S. banks' adoption of the A-IRB would likely affect their competitive position vis-à-vis nonbank rivals.

By nonbank companies, we refer to firms that are neither bank holding companies nor financial holding companies. Nonbank issuers of credit cards (e.g., American Express and General Electric) are typically parent holding companies that originate most of their credit card loans through a bank subsidiary, and these companies usually hold a portion of their on-balance-sheet credit card portfolio at the nonbank parent. ${ }^{8}$ Credit card loans held on balance sheet at the nonbank parent are not subject to bank capital regulation. A change in capital regulations for organizations where the parent company is a bank holding company or a financial holding company could affect the competitive balance between banks and nonbanks by changing the cost to a bank relative to that of a nonbank of holding credit card loans in portfolio.

One potential competitive effect of the proposed bifurcated capital regime (not particular to credit cards) is that A-IRB banks may specialize in holding relatively low-risk portfolios on their books as compared with banks operating under the current regulatory capital regime. ${ }^{9,10}$ This and any other potential competitive effects on relative risk-taking would occur only if the regulatory capital constraint is binding (i.e., the minimum regulatory capital requirement causes banks to hold more capital than they

intended to address potential competitive distortions that might result from more risk-sensitive capital requirements for adopters of Basel II-based rules.

${ }^{8}$ Many credit card banks were originally "nonbank banks" that became banks under the Competitive Equality in Banking Act (CEBA) of 1987. CEBA grandfathered the exclusion from the Bank Holding Company Act of the parent companies of existing nonbank banks, provided they operate within certain restrictions. Companies that newly acquire a CEBA credit card bank are generally subject to the restrictions of a bank holding company or a financial holding company.

${ }^{9}$ This effect is somewhat mitigated since all U.S. banks are subject to the system of prompt corrective action established by the Federal Deposit Insurance Corporation Improvement Act (FDICIA). Under prompt corrective action, increasingly severe penalties are imposed on a bank as its total risk-based capital ratio, its tier 1 risk-based capital ratio, or its tier 1 leverage ratio declines below various trigger levels. In addition, in the U.S., supervisory oversight similar to the proposed pillar 2 of Basel II is already applied; such oversight results in higher minimum capital requirements for increased risk-taking under the current regulatory regime.

${ }^{10}$ Note that this refers to loans the banks hold on their balance sheets. If there is a liquid secondary market for loans or if assets can be easily securitized, then even if regulatory capital requirements affect a bank's incentives to hold assets on its balance sheet, such requirements need not affect a bank's incentive to originate loans even though it may affect the bank's willingness to hold riskier loans on balance sheet. 
would in the absence of the regulatory capital rule, or it causes banks to alter their portfolio composition). A central component of our analysis will be to determine whether regulatory capital requirements for credit card portfolios are currently binding or are expected to be binding under the proposed Basel II regime.

Our analysis, described in more detail in the sections to follow, suggests the following:

1. The A-IRB treatment of credit cards will not have a substantial competitive effect on community banks and most regional banks. Credit cards are not a major product line for community banks or for the vast majority of regional banks. Bank credit card issuance is highly concentrated among a few banks, and this is unlikely to change as a result of changes in required regulatory capital.

2. U.S. banks adopting the A-IRB approach are likely to face sizable increases in total risk-based minimum regulatory capital requirements for their credit card portfolios relative to the current Basel I-based rules, and further, there are likely to be additional substantial increases in required capital during periods of stress on their portfolios. Despite the increases in minimum regulatory capital requirements for credit card portfolios, banks' actual capital holdings for credit cards would still exceed the higher A-IRB regulatory capital minimums (assuming no change in the banks' current balance sheets). However, some A-IRB banks may want to raise their capital allocations for credit card portfolios to maintain a substantial cushion of actual over minimum required capital.

3. Increases in tier 1 regulatory capital minimums for credit cards under Basel II will be much smaller than the increases in the total regulatory capital requirement. Under normal economic circumstances, we believe that A-IRB banks will not be under pressure to allocate additional tier 1 capital for their credit card portfolios.

4. Among major credit-card-issuing banks that would be mandatory A-IRB banks or likely candidates for opting into the A-IRB, current Basel I-based regulatory capital minimums ${ }^{11}$ for

\footnotetext{
${ }^{11}$ Throughout this paper we will use the term regulatory capital requirements to mean the minimum capital requirements under Basel I and the pillar 1 minimum capital requirements under Basel II. That is, we are not
} 
credit card portfolios are far below the levels of capital the market requires these banks to hold. Thus, the current regulatory minimums do not represent a binding constraint on the activities of most large credit card issuers. ${ }^{12}$

5. Since the current minimum regulatory capital requirements are not a binding constraint, the A-IRB should have a competitive effect on credit card activities of banks only if the A-IRB generates an increase in required regulatory capital large enough to cause the affected banks to add to their current level of capital, i.e., to rebuild some of the capital buffer above the regulatory minimum that was lost due to the increase in their minimum regulatory capital requirements.

6. At least for some bank credit card issuers, the estimated increase in required minimum capital for credit cards under A-IRB could be binding, meaning they would need to raise additional capital. Therefore we cannot rule out the possibility that Basel II could create a cost advantage in the credit card market for a small number of regional banks with substantial credit card portfolios and a number of special-purpose credit card banks that would continue to operate under the current Basel I-based rules.

7. Any cost advantage enjoyed by banks using Basel I-based rules would likely be modest. This is because A-IRB banks will likely be able to meet any additional capital needs through allocating additional tier 2 capital (rather than tier 1 capital) for their credit card portfolio and tier 2 capital is not much more costly than other sources of bank funding for credit card portfolios (e.g., securitization funding). Moreover, any disadvantages from higher capital requirements would

speaking of capital requirements that may be imposed based on supervisory judgment, a tool in the U.S. used under both versions of Basel. (Under Basel II these are the pillar 2 capital requirements.)

${ }^{12}$ Many of these banks securitize their credit card receivables. This removes the loans from their balance sheet and lowers their required capital under the current capital rules. Nevertheless, the major bond rating agencies and other market participants assess the capital adequacy of these institutions based on their total managed credit card portfolio (on-balance-sheet credit card assets plus securitized credit card assets). While reducing regulatory capital requirements is certainly one motivation for securitization, it is not the sole motive and not the main motive in most cases. Nonbanks that do not have bank regulatory capital requirements still securitize a substantial portion of their credit card portfolio. Securitization provides substantial liquidity to the credit card market and can efficiently allocate risk across those parties most able to manage the risks. The ability to remove credit card assets from regulatory capital requirements through securitization would continue to be available under the proposed Basel II 
likely be small relative to other competitive factors fueling the ongoing consolidation trend and the growing market dominance of very large credit card issuers. ${ }^{13}$

8. For credit card portfolios that are under stress, the A-IRB generates potentially large increases of required capital. This possibility may affect a bank's desired actual level of capital during nonstressed periods, since A-IRB banks may want to hold a higher capital buffer to hedge the risks associated with these potentially large swings in regulatory capital requirements.

9. The greater responsiveness of regulatory capital to portfolio stress is a general issue across all portfolios at A-IRB banks and does not apply only to credit card portfolios. However, the A-IRB treatment of credit card securitizations magnifies this typical responsiveness of A-IRB capital requirements to stress. In the rare event of extreme financial distress, an A-IRB bank could potentially see a very large, discrete jump in regulatory capital requirements for securitized credit card assets because the A-IRB rules incorporate performance triggers that require the bank to hold more capital as its portfolio performance declines. ${ }^{14}$ This implies a much higher minimum regulatory capital requirement for credit card activities at an A-IRB bank compared to a bank with a similar credit card portfolio and securitization rate but which is operating under the Basel I-based rules.

10. But the difference in numerical minimum regulatory capital requirements for A-IRB and Basel I banks under financial distress likely exaggerates the difference in "effective" capital requirements for several reasons. First, supervisory oversight would likely become the binding constraint for any bank demonstrating similarly poor performance in its credit card portfolio rather than the numerical minimum capital requirements. Second, the market is likely to assess similarly high capital requirements on both sets of banks suffering from poor portfolio performance. Finally,

rules, although less so than under Basel I (see section IV.C). When we consider whether the capital requirements are binding, we mean binding given that banks can securitize their credit card assets.

${ }^{13}$ On June 30, 2005, Bank of America announced it will acquire MBNA, with the action expected to be completed by the end of 2005. The purchase will make Bank of America the largest issuer of credit cards in the United States.

${ }^{14}$ These A-IRB performance triggers are described below in section III.C. 
A-IRB banks might find ways to structure securitizations to avoid hitting the performance triggers of the A-IRB proposal, reducing the need to increase buffer capital stocks because of the A-IRB securitization rules. ${ }^{15}$

11. Nonbank companies that are large credit card issuers will be in a similar competitive position as large bank issuers that do not adopt the A-IRB. Currently, there is no evidence that nonbank companies have a competitive advantage over banks operating under the current Basel I-based rules, since there has been no trend growth in the nonbank share of the credit card market. In fact, Citigroup's recent purchase of the Sears credit card portfolio produced a substantial decrease in the nonbank share of the market. Nonbank companies generally issue credit cards through a bank subsidiary; thus, the competitive effects of the adoption of A-IRB vs. Basel I-based rules should apply to nonbank issuers as well as bank issuers. However, if the nonbank credit card bank subsidiary were subject to the A-IRB framework, the nonbank could avoid any potential competitive disadvantage conferred by the higher capital requirements of A-IRB by transferring more of its credit card assets to the nonbank parent. ${ }^{16}$

Three caveats to the analysis presented in our paper are noteworthy. First, the analysis is based on the current Basel II proposal, which has not yet been written into U.S. rules and is subject to revision as well as to changes in interpretation. Second, the analysis is based on the current Basel I-based rules, which may be modified before the effective date of Basel II. Third, our analysis focuses solely on the domestic U.S. credit card market. We do not consider the potential competitive effects on international credit card operations.

The remainder of the paper is organized as follows: Section II provides descriptive background on the most important features of credit cards and the credit card industry. Section III addresses the likely

\footnotetext{
${ }^{15}$ If a bank did this through raising the level of credit enhancements, then this might not affect our analysis, since regulatory capital requirements would also be raised. However, we cannot rule out the possibility of alternative methods of structuring deals to lessen the likelihood of hitting A-IRB performance triggers.

${ }^{16}$ Under the current proposals, there is no credit card bank subsidiary of a nonbank parent company that would be a mandatory A-IRB bank.
} 
competitive effects of Basel II on credit card activities at community banks. Section IV describes the current and proposed regulatory capital framework. Section V analyzes whether regulatory capital requirements are currently binding or are expected to be binding under Basel II. Section VI analyzes the likely competitive effects of Basel II on banks versus credit card issuers owned by nonbank parents. Section VII presents several likely responses to the A-IRB framework that could be taken by banks to avoid moving from a nonbinding to a binding regulatory capital constraint. Section VIII concludes.

\section{Background}

\section{II.A. Description of Credit Card Loans}

Credit cards loans are revolving extensions of credit to consumers. ${ }^{17}$ Consumers use credit cards in lieu of cash, checks, or debit cards to purchase goods or services. In addition, credit cards can be used to obtain cash advances from banks or ATMs or to pay off other credit card debts through balancetransfer programs.

Credit card loans are generally unsecured. ${ }^{18}$ In a typical credit card transaction, the issuing bank charges a sales draft against the consumer's account and sends the consumer a monthly statement. The consumer may elect to pay off the entire balance or to pay the balance in monthly installments ( 2 percent of the outstanding balance is a common minimum payment). Consumers who pay off their entire balance each month are said to be "transactors," while consumers who carry a balance are said to be "revolvers.",19 (See the Glossary for definitions of these and other terms used in this paper.)

Individual credit card accounts typically have a predefined credit limit. The amount of unused credit (predefined limit less outstanding balances) is sometimes called the "open-to-buy." As of June 30, 2004, summing across all commercial banks, there were $\$ 3,085$ billion in unused credit card

\footnotetext{
${ }^{17}$ Credit cards issued to corporate borrowers are considered small business loans for Call Report purposes and under the Basel II framework. Consideration of corporate credit cards is outside the scope of this paper.

${ }^{18}$ Secured credit cards are treated differently from unsecured credit cards under the A-IRB. We do not address the issue of secured credit cards in this paper.

${ }^{19}$ About 60 to 70 percent of credit card customers are revolvers (Chakravorti and Emmons, 2001). Credit cards with a zero balance and no sales activity for some period of time are termed "inactive" or "dormant" accounts.
} 
lines, nearly five times the $\$ 623$ billion in managed outstandings. ${ }^{20}$ The open-to-buy is typically cancelable at any time at the bank's discretion. However, credit card issuers are reluctant to cancel these open lines for customers who are current on their accounts. If the open-to-buy is closed, the credit card is less valuable to the consumer, and creditworthy customers are likely to take their business elsewhere. In addition, customers with multiple credit cards who become overextended are more likely to become delinquent on those cards with no open-to-buy, since those cards are of less value to the consumer.

Hence, aggressive canceling of the open-to-buy can lead not only to lower growth but to deterioration in a portfolio's credit quality and performance as well.

Credit card loans are "classified" and "charged off" based on retail classification guidelines issued by the Federal Financial Institutions Examination Council. ${ }^{21}$ Credit card loans more than 120 days past due are classified as substandard, while credit card loans more than 180 days past due are charged off the balance sheet. Although the typical utilization rate (the ratio of outstanding balance to credit limit) is approximately 20 percent, charged-off accounts typically have much higher utilization rates.

\section{II.B. The Credit Card Market}

Market Concentration. Although 1,982 commercial banks issued credit cards as of June 30, 2004, the top 10 issuing banking organizations (at the top holder level) manage approximately 93 percent of the $\$ 623$ billion in commercial-bank-managed credit card loans outstanding, while the top 20 issuers manage approximately 98 percent. ${ }^{22}$ This is a higher level of concentration than for commercial banking

\footnotetext{
${ }^{20}$ Managed outstandings are on-balance-sheet credit card loans, plus outstanding credit card receivables sold and securitized with servicing retained or with recourse or other seller-provided credit enhancements, plus seller's interest in credit card securitizations held on balance sheet as securities. (That is, using the Call Report abbreviations, managed outstandings $=$ RCFDB538 + RCFDB707 + RCFDB762.) These figures are based on Call Report data as of June 30, 2004 for commercial banks (credit unions and savings and loans are not included in our sample). All figures in this paper are based on this source unless otherwise noted. Note that about half of credit card receivables are "on balance sheet" in the form of credit card loans, while about half are "off balance sheet" in the form of the investor's interest in credit card asset-backed securities (CC-ABS), i.e., outstanding credit card receivables sold and securitized with servicing retained or with recourse or other seller-provided credit enhancements, net of the seller's interest (see Appendix 1 for a description of CC-ABS structures).

${ }^{21}$ The Federal Financial Institutions Examination Council (FFIEC) is a formal interagency body that sets uniform standards and report forms for the federal agencies examining banks in the U.S.

${ }^{22}$ There is no precise estimate of the amount of credit card lending outside of the banking system. Based on the Board of Governors of the Federal Reserve System G19 report, as of June 2004, outstanding revolving consumer
} 
overall, where the 10 largest banks in the U.S. held less than half of the U.S. banking industry's assets in 2004. Moreover, as is true for commercial banking overall, concentration of credit card lending is increasing. In 1990, the top 10 issuers held only 55 percent of the commercial bank credit card market; by 1998 , this figure had grown to 76 percent. $^{23}$ More recently, Citigroup's purchase of the Sears portfolio and Bank of America's merger with Fleet have significantly contributed to increased concentration in the credit card industry. Once JP Morgan Chase's merger with Bank One is accounted for, the top 10 issuing banks will control approximately 94 percent of credit card loans managed by commercial banks. Moreover, concentration will increase again if Bank of America's proposed purchase of MBNA, which is still subject to regulatory approval, is completed.

Given the size and concentrated nature of the industry, it is not surprising that credit cards are very important products for some of the largest U.S. financial institutions. Table 1 shows several measures of the relevance of credit cards to the overall operations of Citigroup, Inc., Bank One Corp., Bank of America, and J.P. Morgan Chase \& Co as of June 2004. (All figures and tables are at the end of the paper, preceding the appendices.)

Credit Card Specialty Banks: Independent and Affiliated Monolines. As of June 2004, there were 23 independent "monoline" credit card banks. ${ }^{24}$ While some independent monoline banks (MBNA and Capital One) are among the largest credit card issuers, most members of this group are small banks that concentrate almost all of their lending in credit cards (e.g., First National Bank of Marin, Direct Merchants Credit Card Bank, NA). Independent monoline banks account for 42 percent of credit card loans managed within the commercial banking industry. Conditional upon Bank of America's acquisition of MBNA, this percentage will fall substantially in the fourth quarter of 2005.

credit held at banks and nonbanks equaled $\$ 773$ billion. However, while the bulk of the revolving consumer credit number reported in the G19 report represents credit card debt, other types of debt are included. Nevertheless, we can say from the G19 report and the Call Report data that credit card debt managed by commercial banks represents over 80 percent of the credit card market.

${ }^{23}$ Historical data on market shares are based on the Nilson Report from various years.

${ }^{24} \mathrm{We}$ define a monoline as a bank for which credit cards account for 50 percent or more of its managed loan portfolio. Independent monoline banks are defined as institutions for which this definition holds at the highest holder level. 
In addition to the 23 independent monoline banks, large diversified banking organizations typically place their credit card operations in a separate subsidiary with a separate bank charter. ${ }^{25}$ Currently, 15 monoline banks that specialize in credit card lending are affiliated with diversified banking organizations (e.g., Citibank South Dakota, Bank of America USA, and BB\&T Bankcard Corp). The segregation of credit card operations into separate charters greatly facilitates analysis of this line of business. We refer to both the affiliated and independent monoline credit card banks as credit card specialty banks (CCSBs). CCSBs account for 84 percent of all managed credit card loans in the commercial banking system. Credit cards appear to be an extremely profitable business based on Call Report data from credit card specialty banks. For 2003, the return on equity (ROE) for the CCSB industry was approximately 22 percent, compared with about 14 percent for the banking industry as a whole. $^{26}$

Potential A-IRB Banks. Approximately 70 percent of credit card loans managed by commercial banks are currently managed by banks that, according to most industry sources (see Milligan, $A B A$ Banking Journal, and Paletta, American Banker), would meet mandatory A-IRB standards under the current proposal. Some major CCSBs would not meet mandatory A-IRB standards under the current proposal but could choose to "opt in" to the A-IRB approach. Smaller, independent CCSBs are expected to continue operating under current (Basel I-based) capital guidelines.

Funding Strategies. Much of the funding of credit card operations comes from the wholesale market (uninsured borrowing from sophisticated lenders) rather than traditional deposits. Approximately 60 percent of all credit card loans originated by commercial banks are funded off balance sheet in the form of the investors' interest in credit card asset-backed securities (CC-ABS). ${ }^{27}$ Credit card

\footnotetext{
${ }^{25}$ Establishing a separate bank charter to issue credit cards enables a company to headquarter the credit card bank in a state with no usury laws or very high usury ceilings.

${ }^{26}$ The ROEs are based on the book value of equity reported in the Call Reports.

${ }^{27}$ Throughout the paper, securitized credit card assets refer only to the investor's interest in credit card securitization and not the seller's interest (see Appendix 1). The seller's interest in the securitization is on the balance sheet of the credit card issuer.
} 
securitization occurs almost exclusively among the largest issuers and some smaller monoline banks. Buyers of CC-ABS are more likely than insured depositors to carefully monitor their exposures.

On-balance-sheet funding sources include brokered deposits and "other borrowed money." Traditional (nonbrokered) deposits are not an important source of funding for most CCSBs. Given the importance of securitization in financing credit cards, a description of the mechanics of this process is essential to understanding the industry overall and the impact of capital regulation in particular.

Appendix 1 provides details on the mechanics of CC-ABS.

\section{Potential Competitive Effects on Community and Regional Banks of A-IRB for Credit Cards}

Community banks, and even regional banks, have largely exited the credit card market (BB\&T and First National Bank of Omaha are notable exceptions among regional banks). Banks with assets under $\$ 1$ billion, excluding independent monolines, account for 0.20 percent of managed credit card loans in the commercial banking industry, and most banks have no credit card loans. Among the set of community banks that have any credit card loans, the median bank in terms of credit card loans managed does not securitize credit card loans, and credit card loans are less than 0.36 percent of its total loan portfolio, suggesting there are important scale economies in the industry. ${ }^{28}$

Simply put, credit cards are not a significant source of revenue or risk for the great majority of banks. Thus, changes in regulatory capital costs for A-IRB banks are not likely to have any measurable direct or indirect effect on community banks and most regional banks simply because these banks do not compete in this market. However, some of the larger regional banks are more involved in credit cards. To the extent that these banks do not opt in to the A-IRB capital approach, they would face different regulatory capital minimums than the A-IRB banks. However, differences in regulatory minimums are unlikely to place community and regional banks at a competitive disadvantage, since, as we will discuss in more detail later, it is likely that most A-IRB banks would see an increase in their required minimum capital relative to their minimum capital requirement under Basel I-based rules. Indeed, regional and 
monoline banks active in credit cards and remaining under the Basel I-based rules might gain some competitive advantage from the implementation of Basel II.

\section{Current and Proposed Minimum Regulatory Capital Standards}

\section{IV.A. Minimum Regulatory Capital Standards}

Regulatory capital standards are meant to be minimum capital levels that regulators require banks to hold. In addition, current U.S. supervisory guidelines specify higher capital levels for banks that take on higher levels of risk, on a case-by-case basis. As distinct from regulatory capital requirements, economic capital refers to the bank-determined level of capital that is optimal in terms of maximizing return, given the bank's risk tolerance and assuming no regulatory capital requirements. This optimal level of capital for a profit maximizing bank operating free of regulatory constraints incorporates capital's effect on the cost of liquidity, the expected costs of bank distress, and the ease of forcing borrower repayment (Diamond and Rajan, 2000). If a bank's portfolio is transparent, this optimal level is the same as the capital requirement market would assess on the bank. Market participants would require higher returns on investing in a bank if its capital were below its economic (i.e., optimal) capital. Banks with capital levels above economic (i.e., optimal) capital reduce their value by holding "too much" expensive capital financing relative to lower cost debt financing. Since banks' portfolios are not fully transparent, the market (including rating agencies) requires a level of market capital based on its estimate of banks' risk exposures. Regulatory minimum capital levels are designed to be below economic and marketdetermined capital levels so that the regulatory minimums do not unduly affect the credit decisions of bank management. ${ }^{29}$

Healthy banks typically hold a substantial buffer of capital over and above regulatory minimum

\footnotetext{
${ }^{28}$ Credit cards play a small role even for large non-CCSBs. Non-CCSB banks with assets over $\$ 1$ billion but not meeting automatic A-IRB standards account for only 1.6 percent of all credit card loans managed by commercial banks.

${ }^{29}$ The definition of capital used in market assessments differs from the regulatory definition of capital. Market capital is primarily based on equity capital rather than the regulatory definition of capital, which includes some forms of debt finance. When generating a bond rating, the rating agencies assess the likelihood that the firm will become insolvent and thus bond holders will suffer losses. The market definition of capital is more closely aligned
} 
capital requirements. Part of that excess reflects that same gap between economic capital and regulatory capital just discussed. Part reflects a bank's desire to avoid the regulatory costs associated with breaching the minimum regulatory requirements. In the presence of regulatory capital minimums, the valuemaximizing level of capital may no longer be equivalent to economic capital, since markets may take into account the potential costs associated with breaching the regulatory minimums as the result of unanticipated shocks or mistakes. In addition, the size of the buffer will be affected by the degree of risk aversion of bank management. Thus, a bank's desired level of capital may be above the level of economic capital, above the level of capital the market assesses, and above regulatory capital minimums.

As noted, banking authorities purposefully design minimum regulatory capital levels to be below economic capital requirements so as to avoid creating excessive distortions of business decisions. But this does not imply that the regulatory minimum is never binding. Since a bank's capital decision and market pricing of bank securities may reflect an assessment of the potential for breaching regulatory requirements and incurring the associated regulatory costs, the regulation may induce the bank to hold capital in excess of the level of economic capital. Thus, the regulatory minimums may be binding even when economic capital is higher than the regulatory minimums.

Consequently, if the new capital requirement is binding, an increase in the regulatory capital requirement would prompt a bank to increase its level of capital even if its current capital level exceeds the new higher regulatory minimums. ${ }^{30}$ A binding minimum capital requirement implies that the bank faces a trade-off between the gain of holding additional capital as a buffer relative to the minimum requirement versus the cost of holding capital above the desired level of economic capital. ${ }^{31}$

If, based on available information, the market perceives that the risk of breaching regulatory minimums is extremely low, then it is unlikely that there will be any market pressure for the bank to

with tier 1 regulatory capital. Total regulatory capital includes debt instruments that do not protect the firm from insolvency, but do protect the assets of the FDIC.

${ }^{30}$ Alternatively, a bank might adjust the risk profile of its portfolio. 
change its actual capital holdings in response to a marginal change in the regulatory minimums. That is, in cases where regulatory capital requirements are far below economic capital, the regulatory capital minimums are not binding. Thus, if regulatory capital minimums are initially not binding, then either a small decrease or a small increase in those minimums would have no effect on actual capital levels.

On the other hand, a sufficiently large increase in the regulatory capital minimums could generate a potentially new binding capital requirement. Thus, if either the new or prior capital requirements were binding, a change in regulatory capital minimums would affect the actual level of capital a bank holds. ${ }^{32}$ In the case of credit card portfolios, we will argue that the Basel I capital requirements are not binding. However, if the A-IRB generates a large increase in regulatory minimum capital, then the new A-IRB requirement could be a binding constraint, implying a need for the affected bank to raise additional capital. Note that if the Basel II capital requirements are calibrated appropriately, such an outcome would imply that the current regulatory capital regime requires too little capital for credit card activities.

\section{IV.B. Current Regulatory Framework}

Under current U.S. (Basel I-based) capital rules, on-balance-sheet credit card loans are assessed a 100 percent risk weight and, thus, a 4 percent tier 1 and an 8 percent total risk-based capital requirement. Contingent liabilities with an original maturity of one year or less (i.e., short-term commitments) are not generally included as part of risk-weighted assets. Long-term commitments have a 50 percent conversion factor, and the resulting credit-equivalent amount is then risk weighted and included in risk-weighted assets. Undrawn credit card lines are considered short-term commitments in calculating risk-based capital requirements because there is conceptually a separate credit decision before each draw and they are unconditionally cancelable at any time by the bank (see 12 CFR 208, section III.D.2). Therefore, undrawn credit card lines are not assessed a capital charge.

\footnotetext{
${ }^{31}$ Similarly, if capital requirements are binding and a bank holds capital above the regulatory minimum, a reduction in regulatory capital requirements would not be expected to generate a dollar-for-dollar reduction in actual capital held by the bank.

${ }^{32}$ A binding regulatory capital requirement affects the bank's actual level of capital given its risk profile. Alternatively, a binding regulatory capital requirement alters the bank's risk profile or portfolio composition for a given level of capital.
} 
The "investor's interest" in credit card asset-backed securities (CC-ABS) is treated as a loan that has been sold and, therefore, has zero risk-based capital and leverage ratio requirements. ${ }^{33}$ However, the "seller's interest" in CC-ABS - the seller's share of the receivables ${ }^{34}$ in the pool - is typically recorded on the selling bank's balance sheet. Thus, seller's interest has the same risk-based capital and leverage requirements as other on-balance-sheet loans (i.e., 4 percent tier 1 capital and 8 percent total capital are required). ${ }^{35}$ For example, if the receivables in the trust equal \$120 million and the seller's interest is \$20 million, then the banking organization's capital requirement for the seller's interest equals the required capital for $\$ 20$ million in on-balance-sheet loans. The banking organization will also have a variety of other residual interests in the securitization, which typically are effectively deducted from the bank's total capital with at least half of the deduction coming from tier 1 capital (see Appendix 1 for a more detailed discussion of the residual interests subject to deductions). ${ }^{36}$ Spread accounts and cash collateral accounts, if externally rated at BB or higher, would not be assessed a dollar-for-dollar risk-based capital requirement.

The Basel I-based risk-based capital measures are also used to determine whether U.S. banks are "adequately capitalized" under the prompt corrective action (PCA) statutory requirements of the FDIC Improvement Act. In addition, a bank would need a tier 1 leverage ratio (i.e., the ratio of tier 1 capital to unweighted assets) of at least 4 percent to be considered adequately capitalized. Most U.S. banks set capital targets above the PCA "well-capitalized" category. The PCA well-capitalized category requires the ratio of total capital to risk-weighted assets to be at least 10 percent, the ratio of tier 1 capital to riskweighted assets to be at least 6 percent, and the ratio of tier 1 capital to total unweighted assets to be at

\footnotetext{
${ }^{33}$ In some cases, the seller may also own a portion of the investor securities, and these security holdings will have an associated capital charge.

${ }^{34}$ The term "receivables" refers to the credit card assets held by the special-purpose entity (SPE) in a credit card securitization. The SPE buys the payments due on the credit card debt outstanding rather than purchasing the actual account relationship.

${ }^{35}$ The seller's interest is occasionally booked as securities, but these have the same capital requirements under the current Basel I-based regime.

${ }^{36}$ Currently, a bank's risk-weighted asset base is grossed-up to simulate an approximate deduction from capital.
} 
least 5 percent. Under PCA, banks must be well-capitalized to engage in certain activities, such as accepting brokered deposits.

\section{IV.C. The Basel II A-IRB Framework}

Under the proposed Basel II A-IRB approach, the risk weights for on-balance-sheet credit card exposures are a function of the probability of default (PD), loss given default (LGD), and exposure at default (EAD), all of which the bank provides based on its own internal estimates. An A-IRB bank must allocate its credit card portfolio into segments with homogeneous risk characteristics and then estimate the PD, LGD, and EAD associated with each segment. ${ }^{37}$ These internally estimated parameters then generate a regulatory capital requirement based on a "risk-weight" function for qualifying revolving retail exposures (QRREs) developed by the Basel Committee. QRREs include most unsecured revolving lines of credit (e.g., credit card and overdraft protection portfolios). ${ }^{38}$

A key regulatory factor entering the risk-weight function is the asset value correlation (AVC), which reflects the correlation of losses among the assets within a given asset class (e.g., QRREs, commercial and industrial loans, mortgage loans). A high AVC indicates that losses among the assets tend to move together, so that losses during a stress period will likely be large relative to the average loss. A low AVC indicates that losses tend not to be bunched together, so that losses during a stress period tend to stay closer to the average loss rate. Since regulatory capital is meant to serve as a buffer in a stress period, a higher AVC indicates higher required capital, other things equal. The AVC for credit card portfolios is set at 4 percent under the current proposal. ${ }^{39}$

The value of the AVC is combined with the segment's PD and LGD to determine a schedule of regulatory capital risk weights (RW) for the qualified revolving retail exposures. The risk weight, RW, is calculated according to the following formula:

\footnotetext{
${ }^{37}$ See "Internal Ratings-Based Systems for Retail Credit Risk for Regulatory Capital," Federal Register (2004).

${ }^{38}$ To qualify for QRRE treatment under Basel II, credit card portfolios need to demonstrate "low volatility." However, currently there are no concrete criteria for determining low volatility, and so, for the purposes of this paper, we assume that all consumer credit card exposures will be considered under the QRRE risk-weight function.
} 


$$
R W=12.5\left[\left(L G D \times N\left(\frac{N^{-1}(P D)+\left(\sqrt{A V C} \times N^{-1}(0.999)\right)}{\sqrt{1-A V C}}\right)\right)-(L G D \times P D)\right]
$$

$\mathrm{N}(\cdot)$ and $\mathrm{N}^{-1}(\cdot)$ represent the normal cumulative distribution function and its inverse. The value of 0.999 in the term $N^{-1}(0.999)$ reflects the choice of the $99.9^{\text {th }}$ percentile value as the solvency standard for the minimum regulatory capital requirement, which is consistent with a bond rating in the $\mathrm{BBB}+$ to A- range.

To calculate risk-weighted assets (RWA), the bank multiplies the risk weight (RW) by exposure at default $(\mathrm{EAD})$, that is, $\mathrm{RWA}=\mathrm{RW} \times \mathrm{EAD}$. The total minimum regulatory capital required under A-IRB, then, is $\mathrm{K}=0.08 \times \mathrm{RWA}=0.08 \times \mathrm{RW} \times \mathrm{EAD}$, and so required capital per dollar of exposure at default is $\mathrm{k} \equiv \mathrm{K} / \mathrm{EAD}=0.08 \times \mathrm{RW} .{ }^{40}$ Figure 1 shows required minimum regulatory capital per dollar of exposure at default as a function of the PD, holding LGD constant at 90 percent (a reasonable value for credit cards) under the proposed A-IRB approach. For example, if the PD is 1 percent, then the minimum regulatory capital requirement is 2.8 percent of $\mathrm{EAD}$, whereas if the $\mathrm{PD}$ is 5 percent, then the minimum regulatory capital requirement is 8.8 percent of EAD.

Obviously, the A-IRB approach produces more risk-sensitive capital requirements for onbalance-sheet credit card loans than does Basel I. In addition, in contrast to Basel I, the A-IRB requires capital for the risks associated with unused credit card commitments - the so-called "open-to-buy." This charge is introduced through the bank's internal estimate of EAD. For any given segment in the credit card portfolio, the bank estimates the level of additional outstanding balances it expects if its accounts default over the following year. These estimated increases in outstandings are then included in the bank's overall estimate of EAD. The ratio of expected future drawdowns in the event of default to the amount of the open-to-buy is often referred to as the "loan equivalence" (LEQ) of the open-to-buy.

\footnotetext{
${ }^{39}$ This is small compared to the AVCs for other assets, e.g., 15 percent for residential mortgages and 12 percent or
} more for large corporate loans. 
Thus, the A-IRB introduces an effective capital requirement for the open-to-buy that depends on the amount of the open-to-buy, the bank's estimate of LEQ, and the A-IRB risk parameters of the exposure (PD, LGD, and EAD). Because total unused credit card commitments exceed $\$ 3$ trillion at banks (nearly five times total managed assets), even a small effective capital charge on the open-to-buy can have a significant effect on minimum required regulatory capital.

The A-IRB rules also differ from the Basel I-based rules with respect to credit card receivables that banks move off balance sheet through securitization. (The mechanics of $\mathrm{CC}-\mathrm{ABS}$ are described in Appendix 1. Readers not familiar with these arrangements may wish to read Appendix 1 before reading the rest of this section.) First, the gain-on-sale generated by the sale of credit card receivables to the special-purpose trust that issues the securities will be deducted solely from tier 1 capital under Basel II. Under Basel I, the effective deduction from total capital is the same, but a bank would typically deduct half of the gain-on-sale from tier 1 capital and the other half from tier 2 capital. ${ }^{41}$ Other residual interests, such as the portion of an interest-only strip that does not represent a gain-on-sale, would continue to be deducted half from tier 1 capital and half from tier 2 capital.

Perhaps more important, A-IRB banks would be subject to a potential capital requirement for the investor's interest; under Basel I, there is no such capital requirement. This potential capital requirement includes an amount equal to the product of (a) what the A-IRB charge would have been against both the drawn amount and the open-to-buy if the loans were held on balance sheet, and (b) a credit conversion factor $(\mathrm{CCF})$ that depends on the trust's three-month average excess spread relative to deal-specific trapping points. (A trapping point is a predefined level of excess spread below which excess spread is no longer paid to the issuer but is instead held (i.e., "trapped") in escrow as a form of credit enhancement.)

These CCFs are shown below:

\footnotetext{
${ }^{40}$ Note that K/EAD is equal to the term in the square brackets in the RW equation. Because the regulatory capital requirement is intended to cover unexpected losses, expected losses (= LGD $\times \mathrm{PD})$ are subtracted in the formula.

${ }^{41}$ We say that under Basel I, residual interests are effectively deducted from regulatory capital. Technically, under Basel I, banks augment their risk-weighted assets by residual interests rather than deduct them from regulatory capital. However, the method for converting residual interests into risk-weighted assets has the same effect on minimum capital requirements as a deduction from the capital level.
} 
Trust's Excess Spread $^{42}$

$\geq 133.33$ percent of trapping point

$<133.33$ to 100 percent of trapping point

$<100$ to 75 percent of trapping point

$<75$ to 50 percent of trapping point

$<50$ percent of trapping point

\section{Credit Conversion Factor (CCF)}

$$
\begin{array}{r}
0 \% \\
5 \% \\
15 \% \\
50 \% \\
100 \%
\end{array}
$$

Note that the CCF is 15 percent or less as long as the excess spread is at least 75 percent of the trapping point. An excess spread as low as 75 percent of the trapping point generally indicates that a card issuer is experiencing serious credit quality problems in the credit card receivables that have been securitized. $^{43}$

\section{Are Regulatory Capital Requirements a Binding Constraint?}

A central purpose of the Basel Committee's proposed reforms of international capital standards is the creation of minimum regulatory capital requirements that are more sensitive to the level of risk at a banking institution. From an enterprise-wide perspective, this objective can be seen as setting capital standards to achieve a desired minimum level of confidence that an institution would remain solvent should it suffer losses during a period of stress.

In addition to the goal of matching minimum regulatory capital levels to risk at the enterprisewide level, one of the stated goals of the Basel II reform is to more closely align the principles of regulatory capital requirements with those used by banks to measure economic capital for the various types of lending activities. The Basel I flat risk approach to capital for a limited number of asset categories potentially provides incentives for banks to invest more heavily in riskier assets, since required

\footnotetext{
${ }^{42}$ These are the credit conversion factors for "noncontrolled" early amortization provisions. Credit conversion factors for controlled early amortizations are considerably lower. A key feature of the definition of a controlled early amortization is that during the early amortization there are no disproportionate payouts to the investors based on the bank's and investor's relative share of the receivables outstanding at the beginning of each month. In addition, investors must be at risk for a large percentage share of their ownership interest at the start of the early amortization.

${ }^{43}$ Another difference between the A-IRB capital requirements and Basel I-based rules is that for externally rated positions retained by the seller, A-IRB capital charges will generally be higher for tranches having external ratings lower then $\mathrm{BBB}-$ and lower for tranches rated higher than $\mathrm{BBB}$.
} 
capital is not very risk sensitive under the Basel I-based standards. ${ }^{44}$ As illustrated by Calem and Rob (1999), bank value is generally increased through higher leverage for each product up to some level, which they designate as the point of "maximum leverage." The inverse of this maximum leverage level is the economic capital ratio for the product, which maximizes bank value. If the required regulatory capital ratio causes a bank to hold capital in excess of its economic capital level or causes the bank to alter its portfolio composition to adjust to regulatory capital requirements, then, as noted earlier, the regulatory capital requirement is binding. For a given capital level for an individual product, if the regulatory capital requirement is binding, then the bank will have the incentive to reduce the amount of that product in its portfolio and increase its investment in products where the regulatory capital requirement is not binding (that is, where the regulatory capital ratio is less than the economic capital ratio).

All else equal, the economic capital ratio for an asset declines as the credit quality of the asset increases. By assigning capital based on the risk of a particular exposure or group of exposures, the A-IRB approach attempts to reduce regulatory distortions that may discourage banks from holding relatively safe assets in cases where regulatory minimums are above internally estimated economic capital requirements. Misalignment of regulatory capital with economic capital may also encourage banks to engage in costly "capital arbitrage" activities undertaken principally to reduce required capital. For example, a bank faced with excessive (from an economic viewpoint) capital requirements for its relatively safe on-balance-sheet loans might choose to sell or securitize more of these assets than it would if capital requirements were more risk-sensitive.

The incentive to exploit differences in economic and regulatory capital requirements at the margin depends, to some extent, on the degree to which regulatory capital is a binding constraint for a bank. If regulatory capital minimums lie sufficiently below economic capital levels required by internal management evaluations or the capital required by market participants (e.g., counterparties, rating agencies), then regulatory capital requirements would create little incentive to shift on-balance-sheet

\footnotetext{
${ }^{44}$ Both the current Basel I and the Standardized Approach under Basel II are flat asset-based approaches to capital. The capital requirements in both approaches depend on the asset class rather than the riskiness of the particular
} 
assets from relatively safe to relatively risky assets or to marginally reduce regulatory capital requirements through capital arbitrage.

We now address the question of whether regulatory capital requirements are binding for large credit card portfolios. We begin by examining the current capital regime and then address this question for the proposed Basel II A-IRB framework.

\section{V.A. Are Current (Basel I-Based) Rules Binding for Credit Card Banks?}

This section analyzes whether the current minimum regulatory capital requirements are a binding constraint for large credit card portfolios. Our analysis suggests that credit card specialty banks (CCSBs) maintain capital levels far in excess of current minimum regulatory capital requirements and that the total actual capital held by these banks is not driven by the current regulatory requirements. In short, the answer to the subsection's title question is the Basel-I based minimum capital standards are probably nonbinding for most credit card banks. This does not necessarily imply that capital regulation is ineffective for credit card banks, since supervisors may use discretionary authority to require capital above the standard minimum requirements.

Summing across all CCSBs as of June 30, 2004, the aggregate equity capital-to-assets ratio is 17.7 percent (Table 2, column (3), lists this ratio for each CCSB). Similarly, the tier-1-to-total assets ratio for all CCSBs is 15.7 percent, which is far higher than the prompt corrective action minimum of 5 percent for a well-capitalized bank. ${ }^{45}$ The high level of capital held above minimum regulatory capital standards by CCSBs suggests that regulatory standards might not be a binding constraint for these banks.

To investigate this issue more fully, we examine the factors that determine capital holdings at CCSBs using multivariate regression analysis to control for factors affecting the desired capital ratio. Our regression analysis compares equity capital ratios, total capital ratios, and tier 1 capital ratios ${ }^{46}$ for large

portfolio.

${ }^{45}$ Note that the ratio for the group of CCSBs is equivalent to the weighted average of individual CCSB ratios, where the weight equals the individual CCSB's total assets as a share of the total assets of all CCSBs.

${ }^{46}$ Total capital is defined here as tier 1 capital plus tier 2 capital allowable for calculating the risk-based capital ratios. 
CCSBs (mandatory A-IRB banks and potential opt-in banks) relative to commercial bank peers. Our results suggest that credit card banks hold much higher capital-to-assets and capital-to-risk-weightedassets ratios than other commercial banks. However, CCSBs' capital-to-managed asset ratio is similar to that of their commercial bank peers. This suggests that the actual capital held at CCSBs is primarily driven by market considerations rather than regulatory requirements and that the market considers managed assets to be a more reflective measure of credit card banks' total risk exposure than on-balancesheet assets.

\section{V.A.1 Empirical Results}

The sample used for our empirical analysis is a cross-section comprising commercial and industrial banks with BIF or SAIF insurance (i.e., all institutions that file a Report of Condition and Income, the so-called bank Call Report) that have been in existence since 1996. Unless specifically stated otherwise, the data are as of June 30, 2004. Since it is unlikely that small banks will opt in to Basel II, we restrict our sample to banks with total managed assets over $\$ 1$ billion. To create an appropriate peer group for CCSBs, which by definition are primarily lending institutions, we restrict our sample to banks with a managed-loan-to-managed-asset ratio at or above 60 percent. We also delete from our analysis a small number of outliers with very high equity-capital-to-managed-asset ratios (above 25 percent). ${ }^{47}$

These selection criteria produced a final sample of 275 banks. Table 3 shows difference-inmeans tests for the relevant variables for the noncredit card banks versus the credit card banks included in the sample. As shown, on average, credit card banks generally have significantly higher capital-to-totalasset ratios than noncredit-card banks, and they tend to be larger in size. ${ }^{48}$

We regress several measures of capital adequacy on various controls reflecting the demand for capital using ordinary least squares and use one of the Davidson and MacKinnon (1993) adjustments of

\footnotetext{
${ }^{47}$ There were four such outliers. Including them in the analysis vields results qualitatively similar to those obtained when the outliers are excluded.

${ }^{48}$ Our results are qualitatively similar when we test for difference-in-medians rather than difference-in-means.
} 
the standard errors to account for potential heteroscedasticity in the error term. ${ }^{49}$ We report in Tables $4 \mathrm{a}$, $4 \mathrm{~b}$, and $4 \mathrm{c}$ the regression results for our equity capital ratios, total capital (tier 1 capital plus tier 2 capital) ratios and tier 1 capital ratios, respectively. While equity capital is not used to determine compliance with regulatory standards, we include the equity capital ratio in our analysis, since many market analysts concentrate on equity capital when measuring a firm's capital adequacy. ${ }^{50}$

All of the capital ratios are measured as of June 30, 2004. For each definition of capital (equity, total, and tier 1 capital), we use three capital ratios as dependent variables in the regressions: capital-tototal assets, capital-to-risk-weighted assets, and capital-to-managed assets (where managed assets are total assets plus outstanding credit card assets sold and securitized with servicing retained or with recourse or other seller-provided credit enhancements). Note that the managed assets denominator in this last ratio is not used for regulatory calculations under the current or proposed risk-based capital rules or under prompt corrective action guidelines. Still, we look at this ratio because the rating agencies and other market participants often state that they analyze the risk of credit card operations based on the managed portfolio.

Each of the capital ratios is regressed on several variables that are possible determinants of a bank's desired capital ratio. Since economic capital is increasing in risk, higher volatility of earnings could generate a higher desired capital ratio, other things equal. We measure the volatility of earnings by the coefficient of variation of return on equity (ROE), which is the standard deviation in ROE divided by mean ROE. The mean and standard deviation of ROE were calculated over the period 1992 to 2003 using quarterly data. We also controlled for total asset size (in billions) and total asset growth from December 31, 2000 to December 31, 2003 (we exclude 2004 from our estimates of the coefficient of

\footnotetext{
${ }^{49}$ We use the Davidson and MacKinnon (1993) adjustment of the covariance matrix of the estimated parameters, $\left(X^{\prime} X\right)^{-1}\left(X^{\prime} \hat{\Omega} X\right)\left(X^{\prime} X\right)^{-1}$ where $\Omega \equiv$ diagonal matrix with $\frac{n}{n-k} e_{t}^{2}$ on the diagonal, where $e_{t}$ is the estimated regression error, that is, $e_{t}=y_{t}-x_{t} \hat{\beta}, n=$ number of observations and $k=$ number of explanatory variables. This adjustment has been shown to have better small-sample properties than the White (1980) heteroscedasticity-consistent covariance estimator.

${ }^{50}$ Regressions were also run for the tier 1 leverage ratio with results similar to the equity-to-assets ratio. These results are available from the authors upon request. The equity-to-assets ratio allows for a more straightforward computation of an equity-to-managed assets ratio for comparison with risk-based ratios.
} 
variation and growth variables to avoid endogeneity problems). To control for potential nonlinear effects of size and growth, we include asset-size squared and asset-growth squared. Finally, we include an indicator variable for CCSBs (as defined above).

We conducted several robustness checks of our specification. To test whether our results are due to regulatory actions that may have disproportionately affected capital ratios at CCSBs, we estimated our regression models including indicator variable for whether a bank operated under a regulatory enforcement action at any time from January 2000 through June 2004 (we allowed the coefficient on this variable to differ for credit card and non-credit card banks). To test whether our results were due solely to the subprime CCSBs in our sample, we reestimated our regressions with an indicator variable for CCSBs with an average annual charge-off rate from 2000 to 2003 above 7 percent. ${ }^{51}$ Finally, we repeated our analysis, adjusting for mergers that have occurred among the banks in our sample. In particular, since this is a cross-sectional analysis, the only variables that would be affected by mergers would be those with a time-series element to them: the coefficient of variation of ROE and the growth in total assets. We calculate these variables for a bank, accounting for the mergers in which the bank has engaged. Results from these merger-adjusted regressions are presented in Appendix 2. In all cases, our findings on the differences in capital ratios between CCSBs and other banks are very similar to the ones reported here.

The regression results in Model 1 of Table 4a, in which the dependent variable is the equitycapital-to-asset ratio, indicate that the coefficient of variation of ROE, asset size, and growth are highly significant predictors of the capital ratio and have the expected sign. Variability of ROE and more rapid growth are associated with higher capital ratios, while larger banks have lower capital ratios, all else equal. Model 1 shows that the sharp differential between capital levels held by CCSBs and other banks is not completely attributable to differences in earnings volatility, growth rates, or asset size. Even after

\footnotetext{
${ }^{51}$ The bank's average charge-off rate is calculated as the average from 2000 to 2003 of the ratio of the bank's net charge-offs for the year to the bank's average total loans for the year.
} 
controlling for these factors, CCSB capital ratios are, on average, around 9.6 percentage points higher than the equity capital ratio at other commercial banks.

The results for Model 2, in which the dependent variable is equity-capital-to-managed assets, also show highly significant coefficients with the expected sign for earnings volatility, growth, and size. However, when we replace the equity-capital-to-asset ratio with the equity-capital-to-managed-assets ratio as the dependent variable, the coefficient on the dummy variable for credit card banks is not significantly different from zero. In other words, CCSBs' equity-capital-to-managed-assets ratios are statistically indistinguishable from those of other banks. Taken together, these regression results suggest that actual capital levels at CCSBs are more closely tied to total managed credit card assets than to onbalance-sheet credit card assets (on which the current Basel I capital requirements are based). ${ }^{52}$ When we measure the capital ratio with respect to risk-weighted assets in Model 3, we get similar qualitative results with estimated "extra" capital-to-risk-weighted-assets held by CCSBs of 6.2 percentage points. ${ }^{53}$

Table $4 \mathrm{~b}$ reports the regression results with total capital ratios as dependent variables. The regression results are similar with respect to the CCSB dummy variable coefficient. The coefficient is highly significant and large (10.1 percentage points) for the regressions with the ratio of total-capital-tototal-assets as the dependent variable in Model 1. Unlike Model 2 for the equity capital ratios, when the dependent variable is the ratio of total-capital-to-managed assets, the coefficient on the CCSB dummy variable continues to be positive and significant, though rather small in magnitude (1.5 percentage points). Thus, the vast bulk of the differential in the total-capital-to-assets ratio is removed when we use managed assets in the denominator of the capital ratio. Finally, the results for Model 3 indicate that

\footnotetext{
${ }^{52}$ Note that when the dependent variable is the ratio of equity-capital-to-assets, the adjusted $\mathrm{R}^{2}$ is 0.3944 , but it drops to 0.1057 when the dependent variable is the ratio of equity capital-to-managed assets. This is because CCSBs are large outliers compared with the other banks with respect to the equity-capital-to-assets ratio. Thus, when we include the CCSB dummy variable in the regression (Model 1), we are capturing a lot of the variation. But CCSBs are not large outliers compared with the other banks with respect to the equity-capital-to-managed assets ratio. The CCSB variable is not of much help and the $\mathrm{R}^{2}$ falls. To verify this, we regressed the equity-capital-toassets ratio on all the explanatory variables except the credit card bank indicator and obtained an $\mathrm{R}^{2}$ of 0.0535 , similar to the $\mathrm{R}^{2}$ of the regression with the equity-capital-to-managed-assets ratio as the dependent variable.

${ }^{53}$ Note that the means shown in Table 3 similarly suggest that the difference between CCSBs' and non-CCSBs' capital-to-risk-weighted-assets ratios is smaller than the difference between their capital-to-total-assets ratios.
} 
CCSBs' total-capital-to-risk-weighted-asset ratios are about 6.7 percentage points higher than those of noncredit card banks, all else equal. The regression results in Table $4 \mathrm{~b}$ indicate that total asset size, the coefficient of variation, and asset growth are not significant predictors of the ratio of total-capital-toassets or the ratio of total-capital-to-managed assets, but asset size and the coefficient of variation have some significance in predicting the ratio of total-capital-to-risk-weighted assets.

Table $4 \mathrm{c}$ reports the results for the tier 1 capital ratios. These results are qualitatively similar to the results in Tables $4 \mathrm{a}$ and $4 \mathrm{~b}$ with respect to the credit card bank dummy variable. Looking only at Model 3, when the dependent variable is the tier 1 risk-based capital ratio, we estimate that this ratio is 5.3 percentage points higher at CCSBs than at peer commercial banks, other things equal.

\section{V.A.2 Discussion of Empirical Results}

Figure 2 is a relatively simple picture that may help illustrate the reasons for our empirical findings. The graph shows the asset-weighted equity-capital-to-asset ratio and the asset-weighted equitycapital-to-managed-asset ratio aggregated across all CCSBs from 1992 to June 2004 (left axis) as well as the percent of credit card loans securitized (right axis). As can be seen, the equity-to-asset ratio rises steadily as the percent of securitized credit card loans increases. In effect, the growth of securitization meant an effective fall in regulatory required capital for a given level of managed credit card loans. Meanwhile the equity-to-managed-asset ratio has been relatively stable over this period. Again, these patterns are consistent with the view that CCSBs hold capital based on total managed credit card assets rather than on-balance-sheet assets.

Note also that Figure 2 supports the view that CCSBs are unlikely to decrease their buffer capital in response to marginal changes in regulatory capital. Over the 1990 s, as banks increased their securitizations, they maintained a relatively constant equity-to-managed-asset ratio, while their equity-toon-balance-sheet-assets ratio rose. ${ }^{54}$ This implies that banks did not reduce their capital in response to the

\footnotetext{
${ }^{54}$ Quantitative similar results are obtained if tier 1 capital replaces equity in Figure 2.
} 
effective reduction in regulatory capital requirements. ${ }^{55}$ Put another way, as securitization increased, CCSBs increased their buffer stock of capital above the regulatory minimums roughly dollar-for-dollar with the effective decline in their capital requirements. Similarly, if the A-IRB would result in slightly higher regulatory capital requirements, banks (and the market) are likely to remain focused on the capitalto-managed-asset ratio and would not likely increase capital to maintain a relatively constant level of excess capital relative to regulatory minimums. On the other hand, if the A-IRB would result in significantly higher regulatory minimum capital requirements, as might be the case in periods of stress, banks may increase the actual amount of capital held.

Calomiris and Mason (2003) offer further empirical evidence that the level of capital at CCSBs is driven primarily by total managed assets. They show that credit card banks reduce their capital holdings, on average, only about 0.04 percent for each additional percentage point of their portfolio moved off balance sheet.

In sum, the data suggest that actual capital ratios at CCSBs far exceed current minimum regulatory requirements. One potential explanation for CCSBs' behavior in this regard is that they are responding to market pressures, particularly from the bond rating agencies but also from counterparties, especially buyers of CC-ABS, to maintain an adequate capital-to-managed-assets ratio. Indeed, the major U.S. bond rating agencies add all or a substantial portion of assets held in CC-ABS back onto the balance sheet when evaluating the capital position of major issuers. ${ }^{56}$ The desire to maintain a strong bond rating may help explain why CCSBs hold substantial excess regulatory capital over the required minimums.

\section{V.B. A-IRB Capital Requirements with a Zero CCF for the Investor's Interest in Securitized Receivables}

In this section, we use Call Report data on CCSBs to estimate the quantitative change in capital requirements for credit card activities when a bank shifts from Basel-I-based requirements to A-IRB

\footnotetext{
${ }^{55}$ Note that this suggests that regulatory capital arbitrage is not the main motivation for credit card securitization.

${ }^{56}$ See Moody's Report: "Securitization and Its Effect on the Credit Strength of Companies" (2002); Fitch Report: "Basel II Securitization Proposals: Primer and Observations" (2003); and S\&P Credit Week: "Substance, Not Form, of Securitizations Drives Leverage Analysis" (2002).
} 
capital requirement, assuming a zero CCF for the investor's interest in CC-ABS. A positive CCF should be a significant factor when the portfolio is under stress, and we discuss the affects of the CCF rule in the next section.

We first discuss our estimates of the change in the minimum regulatory total capital requirement from switching to A-IRB from Basel-I-based requirements; we then discuss the tier 1 requirement. The A-IRB approach not only changes the calculation of risk-weighted assets, but it also changes how regulatory capital is defined. The changing definition of capital under the A-IRB requires determining an appropriate "apples-to-apples" comparison of the A-IRB requirements to the Basel-I-based requirements. Appendix 3 provides a detailed description of the components of the A-IRB requirements and our method for comparing the A-IRB requirements to the Basel-I-based requirements.

\section{V.B.1. A-IRB Total Capital Requirements}

It is useful to think of the A-IRB total capital requirement for retail credit card assets as being comprised of the following components:

a. The A-IRB measure of unexpected loss (UL) for on-balance-sheet outstanding balances (this includes the seller's interest in securitized receivables) and the UL associated with undrawn lines of credit associated with those outstanding balances. (Note, there is no assessment for the risk exposure from undrawn credit card lines under Basel I-based rules.) UL is based on the A-IRB risk parameters (PD, LGD, EAD), and risk-weighted assets is equal to 12.5 times the estimated UL capital requirement;

b. Capital deductions for expected loss (EL), including any EL associated with the seller's interest in securitized receivables and the undrawn lines apportioned to the seller's interest;

c. Capital deductions for residual interests in securitized receivables (e.g., interest-only strips, cash collateral accounts);

d. Adjustment for the changing definition of eligible loan loss reserves to be counted as capital; 
e. Potential capital requirements arising from a positive CCF associated with the investor's interest in securitized receivables, including the investor's interest proportionate share of undrawn lines (there is no assessment for this under Basel I-based rules).

\section{V.B.1.a. Unexpected Losses (UL)}

To produce estimates of these components we obtained proprietary estimates of PDs, LGDs, and EADs from large, nationally diversified credit card lenders for their outstanding balances and undrawn lines of credit. Using these estimates, we calculated the UL component of the Basel II capital requirement (item a) and then estimated the ratio of Basel II risk-weighted assets (which is 12.5 times Basel II UL capital) to the bank's current Basel I risk-weighted assets. For the representative bank, we obtained a ratio of Basel II risk-weighted assets to the Basel-I-based measure of risk-weighted assets of 94.6 percent. $^{57}$ We then applied this ratio to the sample of CCSBs used in our regression analysis above to obtain an estimate of each bank's risk-weighted assets under Basel II. ${ }^{58}$

\section{V.B.1.b. Expected Losses (EL) and Capital Deductions for Securitizations}

The capital deductions for EL and for residual interests in credit card securitizations (items $b$ and c) are estimated using the CCSBs' Call Report data. EL is estimated by the average lagged charge-off rate from June 2002 to June 2004. The lagged charge-off rate is the current level of charge-offs divided by outstanding balances one year prior, and this measure is commonly used in the industry to measure average loss rates. Data on capital deductions for residual interests in CC-ABS were taken directly from the Call Report. The call reports contain data on a bank's total capital deductions for residual interest in securitizations. ${ }^{59}$ Most CCSBs securitize only credit cards, but some securitize other loans. Where a

\footnotetext{
${ }^{57}$ The bank data are from 2002, a period in which charge-off rates on credit cards were quite high (see Figure 3). Thus, we believe our bank estimates reflect relatively high PDs and relatively high estimates of Basel II riskweighted assets.

${ }^{58}$ We exclude Providian National Bank from this analysis because it has a very different risk profile from the other CCSBs in our regression model.

${ }^{59}$ Charge-offs and capital deductions for residual interests are reported on an aggregate bank level. For a few CCSBs, it was necessary to estimate the proportion of EL and capital deductions for residual interest that was due to the bank's credit card activities.
} 
CCSB securitizes noncredit card loans, deductions for credit cards are apportioned based on the relative amount of residual interest in credit card versus noncredit card securitizations.

The first column of Table 5, Panel A reports the average, the minimum, and the maximum estimates across our sample of credit card specialty banks for the percentage change in total required capital under A-IRB vs. Basel I-based rules, ignoring any adjustments to reserves that qualify as capital. ${ }^{60}$ Our calculations indicate a very large average increase in total required capital under the A-IRB of 44.3 percent. The minimum increase for our sample banks was 19.1 percent while the maximum was 67.0 percent.

Our estimates are changes in the "all-in" capital requirements for a bank's credit card activities, including capital deductions for securitization residuals. Since the effect of CC-ABS residuals on minimum required capital is roughly unchanged under Basel II compared to Basel I, the rate of increase in the all-in capital requirement under Basel II is smaller than the increase in the capital requirement for onbalance-sheet credit card loans. Our estimates (which are not reported in the table) indicate that Basel II raises the capital requirements for on-balance-sheet credit card loans by 67.5 percent. While the all-in charge is, in our view, the relevant measure when analyzing competitive effects, our estimates show that the change in the all-in requirement depends importantly on a bank's rate of securitization and, other things equal, banks that securitize less will see larger increases in required capital. This suggests that incentives to securitize credit card loans may grow with the adoption of Basel II.

\section{V.B.2. Calculating “Eligible” Reserves to Be Counted in Total Regulatory Capital}

Under Basel II there is a change in determining how much of a bank's allowance for loan and lease loss reserves (ALLL) can be counted in total regulatory capital. Under Basel I, eligible reserves can be no greater than 1.25 percent of risk-weighted assets, while for Basel II reserves are counted as capital up to the sum of EL plus 0.6 percent of risk-weighted assets. This calculation is done for the bank's entire risk-weighted portfolio rather than a separate calculation for each asset type.

\footnotetext{
${ }^{60}$ The average estimates are unweighted bank averages. Weighting by assets does not make a substantial difference.
} 
While it is often stated that Basel I and Basel II set capital requirements for a particular activity and the capital requirements for the activity are independent of other portfolio decisions, this is not strictly correct because the "cap" on eligible reserves depends on the bank's entire portfolio. The rule for calculating eligible reserves implies that the effective marginal regulatory capital requirement for the exact same activity can differ across banks regardless of which capital regime they operate under. This raises a complex issue for analyzing the competitive effect of Basel II on any asset class.

Taken independently, credit card loan portfolios held on balance sheet typically generate reserves well in excess of the 1.25 percent of risk-weighted assets cap under Basel I rules. To see why, consider a bank that generates risk-weighted assets only through its credit card lending. Assume that the bank's loan loss reserves are set to cover 75 percent of annual EL, while its EL is 5 percent of credit card loans outstanding. This would mean that reserves would equal 3.75 percent $(=0.75 \times 5$ percent $)$ of credit card loans outstanding. ${ }^{61}$ Under Basel I, risk-weighted assets for on-balance-sheet credit card exposures generally equal credit card loans outstanding. The cap on reserves that count as capital implies that the hypothetical bank would only count as capital its reserves up to 1.25 percent of credit card loans outstanding and the bank would be holding ineligible reserves equal to 2.5 percent of outstanding loans.

The situation is substantially different under Basel II where the bank could count all of its reserves as capital, since reserves are less than EL. In the hypothetical case given above, Basel II's more generous inclusion of reserves would create a significant source of regulatory capital.

However, analyzing the effect for credit card activities of the change in eligible reserves under Basel II is more complex when we consider banks that engage in a diversified set of activities, where some of these activities generate reserves that are below the Basel I cap of 1.25 percent of risk-weighted assets. For example, under Basel I, CCSBs can generate more eligible reserves without raising actual reserves by increasing securitization of the credit card portfolio. Credit card securitization residuals subject to dollar-for-dollar capital requirements generate risk-weighted assets without generating loan loss

\footnotetext{
${ }^{61}$ These assumptions are reasonable approximations for many large CCSBs given the data on reserves and chargeoffs from the Call Reports.
} 
reserves. $^{62}$ Thus, even at the CCSB level, different rates of securitization can generate a wide disparity in the level of ineligible reserves generated by credit card activities. Since on-balance-sheet credit card loans typically generate ineligible reserves when considered in isolation, the effect of the change in the rules for determining eligible reserves is bank-specific and is dependent on the level of securitization and the mix of other products held on the balance sheet. In some cases, the reserve cap might not be binding on a bank-wide basis, and consequently, there would be little or no benefit to the bank if Basel II increases the maximum level of reserves that can be included in regulatory capital.

Because of the complexities associated with calculating eligible reserves, we are able to provide only some bounds on the estimated effect on required capital of a shift from Basel I-based rules to Basel II's A-IRB rules rather than precise estimates. Our bounds are derived by analyzing polar cases: a case where the change from Basel I to Basel II has a large effect on the amount of reserves that can be counted as capital and a case where it has little effect on eligible reserves. For the first case, we calculate the change in the effective capital requirement at the CCSB level. Typically CCSBs hold large amounts of ineligible reserves under Basel I that will be included in capital under the A-IRB, generating a substantial benefit under Basel II from the increase in the cap on eligible reserves. For the second case, we calculate the change in the effective capital requirement under the assumption that the bank does not face a binding constraint on reserves to be counted in regulatory capital under Basel I. These two polar cases provide bounds on the likely effect on capital requirements of a shift from Basel I to Basel II A-IRB.

Recall that our estimate of the increase in total capital requirements under the A-IRB assuming no binding cap on reserves equaled 44.3 percent for the managed credit card portfolio (as shown in column 1 of Table 5, Panel A). If we estimate the change in eligible reserves at the CCSB level (column 2 of the Table 5, Panel A), then the estimated increase would be reduced for the average CCSB to 23.6 percent.

\footnotetext{
${ }^{62}$ These residuals are multiplied by 12.5 when generating risk-weighted assets for the purposes of determining maximum eligible reserves.
} 


\section{V.B.3. A-IRB Tier 1 Capital Requirements}

We now turn to estimating the effect on the minimum tier 1 capital requirements of a shift from Basel I to the A-IRB of Basel II. Appendix 3 provides a detailed description of the components of the A-IRB tier 1 requirements and how we compare the A-IRB requirements to the Basel I requirements.

The A-IRB tier 1 capital requirements for retail credit card assets comprise the following components:

a. One half the total capital requirement for UL that enters the total capital requirement discussed above;

b. Tier 1 capital deductions for residual interests in securitized receivables. Whereas residual interests have roughly the same effect on the total capital requirement under the A-IRB and under BaseI I-based rules, the A-IRB applies a higher proportion of these deductions to tier 1 capital;

c. A capital deduction equal to one half of any shortfall in loan loss reserves relative to EL. There is no adjustment to tier 1 capital if reserves equal, or exceed, EL.

We have already discussed the estimation of risk-weighted assets (item a) under the A-IRB in discussing the total capital requirement. We estimated a ratio of Basel II risk-weighted assets to the Basel I-based measure of risk-weighted assets of 94.6 percent. The main change in the A-IRB treatment of credit card securitization residuals (item b) is that the after-tax gain-on-sale component of those residuals is deducted entirely from tier 1, whereas typically under Basel I-based rules the gain-on-sale is effectively deducted half from tier 1 and half from tier $2 .{ }^{63}$ Thus, the A-IRB change in the treatment of the after-tax gain-on-sale will effectively increase required tier 1 capital by approximately half of the gain-on-sale while leaving total capital requirements unchanged.

\footnotetext{
${ }^{63}$ As mentioned previously, securitization residuals were technically not deducted from capital under Basel I rules, but they were grossed up into risk-weighted assets to ensure that the total capital ratio after grossing-up equaled the capital ratio if the residuals had been deducted.
} 
Bank Call Reports do not directly report the gain-on-sale from CC-ABS; however, the gain-onsale is typically closely tied to the valuation of the interest-only strip (I/O strip) for credit card securitizations reported on the Call Report. For our calculations of the tier 1 requirements under Basel II, we estimate the after-tax gain-on-sale for CCSBs by the after-tax I/O strip. ${ }^{64}$

The final component of the A-IRB tier 1 capital requirement is the deduction from tier 1 of half of any reserve shortfall that exists. The evidence from Call Report data suggests that large CCSBs hold loan loss reserves that are below EL. However, the A-IRB calculation of the reserve shortfall is done on an aggregate portfolio basis. Many of the CCSBs are subsidiaries of bank holding companies that might not have a shortfall on an aggregate basis. Thus, allocation of the reserve shortfall to specific asset classes raises the same types of conceptual issues as the allocation of eligible reserves, because credit card portfolios typically have a reserve shortfall while other loan portfolios do not. However, note that allocating the shortfall at the CCSB level rather than at the parent holding company level likely raises the estimated increase in A-IRB tier 1 requirements, whereas estimating eligible reserves at the CCSB level rather than at the parent company level likely reduces the increase in total required capital under the A-IRB. ${ }^{65}$

We again address the issue of allocation by reporting the estimates at the CCSB level as well as under the assumption that there is no reserve shortfall. In effect, we are calculating the A-IRB estimates under the two extreme assumptions: either the bank is a monoline credit card company or the bank is a diversified holding company where the tier 1 shortfall is not a binding constraint.

Table 5, Panel B reports our estimates of the percent change in tier 1 requirements under the A-IRB as compared to Basel I-based rules under these two assumptions. Assuming no reserve shortfall, the average increase is only 2.2 percent. But the average increase for CCSBs in our sample adjusting for the reserve shortfall is 13.2 percent. Table 5 also reports the minimum and maximum estimates and, as

\footnotetext{
${ }^{64}$ We assume a tax rate of 35 percent.

${ }^{65}$ The simple intuition for this result is that as compared to other bank portfolios, credit cards produce a high EL relative to risk-weighted assets under Basel I, and credit card portfolios generally hold low reserves relative to EL.
} 
with our results for total regulatory capital, there is a wide dispersion. Note that this dispersion is not due to differences in risk-weights for on-balance-sheet credit cards across institutions. Rather the dispersion occurs principally because of different rates of securitization and different reserving practices.

To summarize, we estimate that a shift from Basel I-based rules to the Basel II A-IRB rules would imply an average increase in total required capital ranging from 23.6 percent to 44.3 percent, and an average increase in required tier 1 capital ranging from 2.2 percent to 13.2 percent. This range between the lower and upper estimates represents different approaches to allocating eligible reserves for the Basel I total capital calculation and allocating the reserve shortfall in the A-IRB tier 1 calculation.

\section{V.B.4. Estimated Change in Actual Capital Ratios from Switch from Basel I-Based Rules to $A-I R B$}

The next step in our analysis is to calculate the change in the actual capital ratio for a CCSB shifting from the Basel I-based rules to the A-IRB assuming it maintained its current level of capital. For this purpose, we approximate the change in the actual capital ratio under the assumption that the percentage change in required capital from a switch to A-IRB from Basel I-based rules arises from an equivalent percentage change in the denominator of the regulatory capital ratio rather than any change in the net deductions from capital under A-IRB compared to the Basel I-based rules. (Note that this assumption understates the percentage change in required capital to the extent that the net deductions as a fraction of risk-weighted assets rises under A-IRB compared to the Basel I-based rules. ${ }^{66}$ Table 6 shows the results of our calculations of the implied change in the capital ratio for the average CCSB given our estimates for the increase in required capital when moving from Basel I-based rules to the A-IRB (shown in Table 5) for a hypothetical average CCSB bank.

\footnotetext{
${ }^{66}$ To see this, let $\left(\mathrm{C}_{\text {II }}-\mathrm{D}_{\text {II }}\right) / \mathrm{RWA}_{\text {II }}$ be the required minimum capital ratio under A-IRB, $\left(\mathrm{C}_{\mathrm{I}}-\mathrm{D}_{\mathrm{I}}\right) / \mathrm{RWA}_{\mathrm{I}}$ be the required capital ratio under the Basel I-based rules, where $\mathrm{C}=$ minimum regulatory capital, $\mathrm{D}=$ net deductions from capital, and RWA $=$ risk-weighted assets. Then, $\mathrm{C}_{\mathrm{I}}=0.08 \mathrm{RWA}_{1}+\mathrm{D}_{1}$ and $\mathrm{C}_{\mathrm{II}}=0.08 \mathrm{RWA} \mathrm{A}_{\mathrm{II}}+\mathrm{D}_{\mathrm{II}}$. Let $\gamma$ be the percentage change in required minimum capital that a shift from the Basel I-based rules to A-IRB rules would imply. Then $\mathrm{C}_{\mathrm{II}}=(1+\gamma) \mathrm{C}_{\mathrm{I}}$, which implies, $0.08 \mathrm{RWA}_{\mathrm{II}}+\mathrm{D}_{\mathrm{II}}=(1+\gamma)\left(0.08 \mathrm{RWA}_{1}+\mathrm{D}_{1}\right)$, and so $\gamma=\left[\left(0.08 \mathrm{RWA}_{\mathrm{II}}+\right.\right.$ $\left.\left.\mathrm{D}_{\mathrm{II}}\right) /\left(0.08 \mathrm{RWA}_{1}+\mathrm{D}_{1}\right)\right]-1$. Note that if deductions were zero, then $\gamma=\left(\mathrm{RWA}_{\mathrm{II}} / \mathrm{RWA}_{1}\right)-1$, i.e., the percentage increase in capital would equal the percentage increase in risk-weighted assets. If we approximate $\gamma$ by $\left(\mathrm{RWA}_{\mathrm{II}}\right.$ $\left./ \mathrm{RWA}_{1}\right)-1$, we will understate $\gamma$ whenever $\gamma>\left(\mathrm{RWA}_{\mathrm{II}} / \mathrm{RWA}_{1}\right)-1$. This occurs when $\left[\left(0.08 \mathrm{RWA} \mathrm{A}_{\text {II }}+\mathrm{D}_{\mathrm{II}}\right) /\right.$ $\left.\left(0.08 \mathrm{RWA}_{1}+\mathrm{D}_{1}\right)\right]-1>\left(\mathrm{RWA}_{\mathrm{II}} / \mathrm{RWA}_{1}\right)-1$, i.e., $\left(\mathrm{D}_{\mathrm{II}} / \mathrm{RWA}_{\mathrm{II}}\right)>\left(\mathrm{D}_{\mathrm{I}} / \mathrm{RWA}_{\mathrm{I}}\right)$.
} 
This hypothetical bank is based on the average bank in our sample of large CCSBs used in our regression analysis. The current average total risk-based capital ratio for this sample is 18.5 percent and the average tier 1 risk-based capital ratio is 15.0 percent (see Table 3). As shown in Panel B of Table 6, for this hypothetical average CCSB, our higher estimate of a 44.3 percent increase in the minimum required total capital would imply a reduction in the capital ratio to 12.8 percent, a reduction of 5.7 percentage points.

Our estimates indicate that the new effective total risk-based capital ratio would still be above the 8 percent regulatory requirements and above the 10 percent "well-capitalized" criterion in the prompt corrective action requirements of FDICIA. Moreover, the total risk-based ratio would be slightly higher than the 12.1 percent average total risk-based capital ratio at other commercial banks (see Table 3). Nevertheless, the excess of total risk-based capital held at CCSBs would be substantially reduced, and we cannot rule out the possibility that the A-IRB would generate a binding total risk-based capital requirement (i.e., bank management, the market, and the rating agencies might be less comfortable with the actual capital held relative to the new regulatory capital requirements).

Our estimated effect on the tier 1 risk-based capital ratio is more modest. As shown in Panel C of Table 6, our higher side estimate of a 13.2 percent increase in minimum required tier 1 capital after adoption of the A-IRB would imply a reduction in the average bank's tier 1 capital ratio from 15.0 percent to 13.3 percent, a reduction of 1.7 percentage points. This estimate indicates that the average CCSB tier 1 ratio would still far exceed the 4 percent minimum requirement and would remain substantially higher than the 10.5 percent average tier 1 ratio at other commercial banks.

Although our estimates imply that the capital ratios of the average CCSB would still exceed regulatory minimum requirements, there is no simple test to determine whether a level of buffer capital held by a bank is sufficiently large to make the minimum capital requirement nonbinding. The estimated substantial increase in required capital under Basel II suggests the possibility that A-IRB CCSBs would move from a nonbinding total capital requirement under Basel I to a binding capital requirement under Basel II, as their buffer relative to regulatory requirements narrows substantially. However, the case that 
the tier 1 regulatory requirement will become a binding constraint under Basel II is considerably weaker, since our estimates indicate that the average credit card bank would still have a significantly high buffer over the Basel II regulatory minimum.

What about CCSBs with increases in tier 1 requirements that are higher than the average CCSB? Increases in the tier 1 requirement derive principally from two sources: the shortfall in reserves relative to EL, and the full deduction of the gain-on-sale from tier 1 capital. If a CCSB has a larger reserve shortfall than other CCSBs with similar ELs, then it would seem reasonable that that CCSB would receive a relative increase in capital requirements. As for the change in the gain-on-sale treatment, this item increases in importance directly with the rate of securitization. That is, a bank that securitizes more will tend to see a higher increase in required tier 1 capital upon adopting Basel II. However, under both Basel II and Basel I, a higher securitization rate substantially reduces capital requirements relative to the managed portfolio, whereas market capital requirements, which are based on managed assets, are not greatly affected by securitizations. Thus, those CCSBs with a relatively high increase in tier 1 requirements due to the Basel II treatment of gain-on-sale will be banks that receive substantial capital relief from securitization activities. These banks are the least likely to face a binding tier 1 requirement because the divergence between regulatory capital and economic capital is greatest for these banks.

\section{V.C. A-IRB Capital Requirements with a Positive Credit Conversion Factor for the Investor's Interest in Securitized Receivables}

This section addresses the likelihood that performance by a CC-ABS will trigger a positive credit conversion factor (CCF) and how this may affect required capital under the A-IRB. Under the A-IRB proposal, CCFs for the investor's interest in securitized receivables and the share of undrawn lines apportioned to the investor's interest are a function of deal-specific trapping points. Unfortunately, data regarding deal-specific structure for a large cross-section of CC-ABS are not easily obtained. However, CC-ABS deals are somewhat standardized among the larger, higher quality issuers. A common trapping point for excess spread is 4.5 percent, i.e., when the three-month average excess spread falls below 4.5 percent, the excess spread is "trapped" in an escrow account instead of being paid to the issuer. Using 4.5 
percent as the presumed relevant trapping point for A-IRB banks, CCF thresholds are hit when excess spread reaches 6.0 percent, 4.5 percent, 3.375 percent, and 2.25 percent (resulting in CCFs of 5 percent, 15 percent, 50 percent, and 100 percent, respectively). We analyze historical data on CC-ABS to assess the frequency with which these thresholds have been reached. Data on excess spreads for publicly traded and rated $\mathrm{CC}-\mathrm{ABS}$ deals are available from several sources. Our data come from ABSNet, which provides monthly measures of excess spread and its component parts from 1996 to 2004.

Out of 126 floating-rate CC-ABS deals measured over 6,432 deal-month observations, ${ }^{67} 47.2$ percent of all deal-month excess spreads were at the 0 percent CCF, 38.5 percent of all deal-months were at the 5 percent CCF, 13.1 percent of all deal-months were at the 15 percent CCF, 0.96 percent of all dealmonths were at the 50 percent CCF, and 0.06 percent of all deal-months were at the 100 percent CCF. Thus, only about 1 percent of deal-months had a CCF of 50 or 100 percent, suggesting that performance triggering a CCF above 15 percent is highly unusual. Looking across all deals, 22 deals reached the 50 percent CCF or higher at some point, but they typically did not stay at that level for long.

This set of deals may not be completely representative of the type of deals that will occur going forward. Deals pre-dating 1999 were disproportionately likely to have excess spreads below the proposed CCF triggers as compared to more recent deals. Moreover, CC-ABS deals may be less likely to hit CCF thresholds going forward than historical data suggest. Deal structure is endogenous and will likely adjust to the new regulatory rules. The A-IRB CCFs depend on the relationship of excess spreads to dealspecific trapping points. ${ }^{68}$

\footnotetext{
${ }^{67}$ Older CC-ABS were often fixed-rate deals. Some of these deals hit excess spread targets when interest rates rose. We do not include these in our sample for two reasons. First, virtually all new deals are now structured as floatingrate deals. Second, since the decline in excess spread for fixed-rate deals was not a credit event, regulators allowed banks to restructure those deals when excess spreads fell without considering the restructuring recourse.

${ }^{68} \mathrm{CC}$-ABS deals contain many forms of credit enhancement and other protections to bondholders, of which excess spread reserve accounts are only one. Future deals are likely to be engineered to substitute other forms of credit protection for lower excess spread trapping points while maintaining the same overall level of credit protection for investors. Whether this affects the safety and soundness of banks depends on whether the market assesses appropriate capital requirements. Note also that the A-IRB regulatory capital requirements might be changed to encompass new types of deal structures.
} 
Based on past data, reaching the 5 percent and 15 percent CCF will be fairly common. Even though we believe that the probability of hitting a 15 percent CCF might decline substantially in the future, we estimate the effect on A-IRB capital requirements relative to Basel I for large CCSBs, assuming that they trigger a 15 percent $\mathrm{CCF}$.

For the CCSBs in our regression sample, the weighted average rate of securitization was 60.7 percent. ${ }^{69}$ With this rate of securitization, a 15 percent CCF produces a 23.2 percent increase in credit card receivables outstanding that would then become subject to regulatory capital requirements under the A-IRB. To see this, consider the simple example in Panel A of Table 6. This hypothetical bank has \$39.3 million in owned credit card receivables and an investor's interest in securitized credit card receivables of $\$ 60.7$ million (which corresponds to a securitization rate of 60.7 percent). If a 15 percent CCF is triggered, then the bank must then hold capital against 15 percent of its securitized receivables, i.e., against an additional $\$ 9.1$ million of credit card receivables that move back onto the balance sheet. This represents an increase of 23.2 percent (=\$9.1 million $/ \$ 39.3$ million) in outstanding credit card receivables for which the bank must hold capital, and the bank must also hold capital against the exposure from the open-to-buy associated with the additional $\$ 9.1$ million in outstanding balances.

Our previous analysis suggested that for a fixed set of credit card balances outstanding and a CCF of 0 percent, the A-IRB might generate an increase in both required total risk-based capital and tier 1 riskbased capital. Now we consider these effects along with the effect of triggering a 15 percent CCF for the average large CCSB. The average large CCSB has a total risk-based capital ratio of 18.5 percent. Switching to A-IRB might imply an effective 23.6 to 44.3 percent increase in risk-weighted assets for a credit card portfolio using our estimates of the total capital impact of the A-IRB on our two bank credit card portfolios. In our example shown in Table 6, a bank with Basel I risk-weighted assets of \$39.3 million whose only risk-weighted assets are from credit card loans would see an increase in risk-weighted assets to the range of $\$ 48.6$ million to $\$ 56.7$ (and a resulting fall in the total risk-based capital ratio from 
18.5 percent to between 12.8 to 14.9 percent). As shown in Panel B of Table 6, if a 15 percent CCF were then triggered, as discussed earlier, this would imply an additional 23.2 percent increase in risk-weighted assets on which capital must be held, which means risk-weighted assets effectively increase to a range of \$59.8 million to $\$ 69.8$ million, and the risk-based capital ratio falls further to between 10.4 and 12.1 percent.

Thus, the shift to A-IRB combined with a triggering of the 15 percent CCF implies a large estimated decline in the average total risk-based capital ratio for our large CCSBs - by 6.4 to 8.1 percentage points from the original 18.5 percent. The additional decline in the total risk-based capital ratio could be greater than the 6.7 percentage points of "extra" total risk-based capital that CCSBs currently hold as shown in the last column of Table $4 \mathrm{~b}$. In other words, on average, we estimate the CCSBs' risk-based capital ratios could end up being lower then the ratios at peer banks should a 15 percent CCF be triggered.

Focusing on tier 1 estimates, we previously showed that moving to the A-IRB framework with a $\mathrm{CCF}$ of 0 percent could result in an effective 2.2 to 13.2 percent increase in risk-weighted assets for a credit card portfolio. In our example shown in Panel C of Table 6, a bank with Basel I risk-weighted assets of $\$ 39.3$ million whose only risk-weighted assets are from credit card loans would see an increase in risk-weighted assets to the range of $\$ 40.2$ million to $\$ 44.5$ million (and a resulting fall in the total riskbased capital ratio from 15.0 percent to between 13.3 to 14.7 percent). If a 15 percent CCF were then triggered, this implies an additional 23.2 percent increase in risk-weighted assets on which capital must be held, which means risk-weighted assets effectively increase to a range of $\$ 49.5$ million to $\$ 54.8$ million, and the risk-based capital ratio falls further to between 10.8 and 11.9 percent.

Recall that our regression analysis suggested that large CCSBs hold, on average, 5.3 percentage points higher tier 1 capital ratios than other banks with similar risk characteristics (see the last column of Table 4c). We estimate that the combined effects of a movement from Basel I-based rules to A-IRB plus

\footnotetext{
${ }^{69}$ We define securitized credit card assets as the investor's interest in the securitized receivables, since the seller's interest remains on the bank's balance sheet. Note that the 60.7 percent rate of securitization for our regression
} 
a 15 percent CCF would lead to a decrease in tier 1 capital of between 3.1 and 4.2 percentage points. Thus, our estimates suggest that the differential in tier 1 capital held by CCSB and other banks would be largely eroded, but not completed eliminated.

We argued earlier that the very high level of CCSBs' capital ratios relative to non-CCSB banks' capital ratios when measured using on-balance-sheet assets indicated that the required regulatory capital ratios were not binding on large CCSBs that securitized a substantial portion of their credit card loans. However, the estimates just presented indicate that:

1. The regulatory capital requirement for total capital under the A-IRB with a zero CCF will generate capital ratios at CCSBs that are more in line with other commercial banks. When combined with a 15 percent CCF, some CCSBs would likely be near, or below, the regulatory minimum for total capital;

2. The regulatory requirement for tier 1 capital under the A-IRB would generate reductions in tier 1 capital ratios that would still be far above regulatory requirements and far above other commercial banks. When combined with a 15 percent CCF, most CCSBs would still have tier 1 capital ratios substantially above regulatory requirements; however, CCSB tier 1 capital ratios would fall substantially and would be more in line with other commercial banks.

Although our results on the effects of triggering a 15 percent CCF suggest that A-IRB CCSBs might be disadvantaged relative to CCSBs operating under Basel I-based rules, these findings cannot be conclusive for several reasons. First, if CCSBs operating under the Basel I-based rules and banks under A-IRB have similar losses during periods of stress, the market is likely to assess similarly high capital requirements on both sets of banks. That is, while regulatory capital requirements under the A-IRB could rise substantially for individual banks (and fall for others), market requirements are likely to also rise during periods of stress, and the market requirement might continue to be well above the regulatory requirement. Second, it is likely that, during periods of poor performance, any bank might be constrained 
by bank supervisors, whether or not it was using the A-IRB approach. That is, supervisory oversight might become a binding constraint for any bank demonstrating similarly poor performance in its credit card portfolio. In that case, while the numerical minimum capital requirements during a period of portfolio stress might be much higher under the A-IRB, the "effective" capital requirements during periods of stress for these portfolios might not be very different. Finally, it is possible that A-IRB banks would be able to find ways to structure their securitizations to substantially lower the probability of hitting the performance triggers (i.e., positive CCFs) of the A-IRB proposal.

During a period of extreme stress, excess spreads might decline sufficiently to trigger a CCF of 50 percent or 100 percent. This would undoubtedly lead to a much higher regulatory capital requirement for A-IRB banks relative to banks subject to Basel I-based regulatory capital requirements. Moreover, the higher capital requirements are likely to be binding under the A-IRB, since the bank-estimated risk parameters (PD, LDG, and EAD) will likely increase in a period of distress. However, as we have argued, it is highly likely that any bank - those operating under the A-IRB and those operating under Basel I-based capital rules - suffering similar levels of stress would be severely constrained by bank supervisors. Thus, it is unlikely that an A-IRB bank facing such extreme financial stress would be disadvantaged relative to banks operating under Basel I rules and facing similar levels of stress. ${ }^{70}$

To summarize, it appears that there is only a small likelihood that CC-ABS would trigger CCFs for the investor's interest that exceed 15 percent. Our estimates suggest that CCSBs can absorb a substantial increase in risk-weighted assets from the A-IRB, but the trigger of the 15 percent CCF under A-IRB for a CCSB's entire credit card portfolio could significantly reduce its buffer capital and the minimum capital requirement would then likely represent a binding constraint for the A-IRB bank. In contrast, CCSBs operating under Basel I-based rules would not face a binding minimum capital constraint

\footnotetext{
${ }^{70}$ A-IRB capital ratios are publicly disclosed. It is possible that A-IRB banks would be disadvantaged by this public reporting of their capital ratios. However, since performance of credit card securitizations is typically publicly reported, market participants would be well aware of severe stress for credit card portfolios of major issuers even if they are not A-IRB banks.
} 
(although they might also face higher supervisory and market capital requirements if their portfolios were under stress).

\section{V.D. Are Regulatory Capital Requirements a Binding Constraint? - Section Summary}

We cannot rule out the possibility that the A-IRB could generate binding total regulatory capital requirements for credit card portfolios even if CCFs are zero. We believe that the A-IRB would likely generate a binding tier 1 and total capital requirements in periods when there is a positive CCF. Since CCSBs operating under the current Basel I-based rules do not appear to face a binding regulatory constraint, it is possible that this could provide some advantage for the Basel I-based CCSBs and might provide a disincentive for independent monoline CCSBs from opting in to the A-IRB. Moreover, our results suggest that CCSBs with riskier portfolios and high levels of securitization might find it necessary to hold more capital to be able to manage themselves through stressful periods, providing more advantage to non-A-IRB banks.

Because a bank's level of securitization - not only of credit card receivables but of its other assets as well - affects the capital requirement under A-IRB, we believe that the effects of A-IRB will differ across banks depending upon their on- and off-balance-sheet structure.

Note that our analysis has abstracted from another possible motive for holding capital. Namely, banks may wish to guard against the increased volatility of required capital levels under the A-IRB as compared to Basel I-based rules. The potential to hit a positive CCF trigger is a major factor increasing the volatility of required capital levels under the A-IRB. Also, under the A-IRB approach, required regulatory capital could be more volatile than under the current Basel-I based rules, as required regulatory capital under A-IRB rises and falls with changes in the charge-off rates on credit cards. Thus, A-IRB might result in higher actual capital levels of CCSBs, even when the CCF is zero. In other words, banks may desire higher levels of buffer capital under A-IRB rules than under the current Basel I-based rules. 


\section{The Potential Effect of A-IRB on Nonbank vs. Bank Competition in the Credit Card Industry}

Nonbank companies, such as Morgan Stanley, American Express, General Electric, and (until recently) Sears, are substantial competitors in the credit card industry. However, no major competitor in the credit card issuing industry operates completely outside of the banking system. Major nonbank credit card issuers have all chosen to operate significant banking subsidiaries (e.g., Discover Bank, American Express Centurion Bank, GE Money Bank, and Sears National Bank, respectively). Furthermore, many private-label store and gas cards are operated within banking subsidiaries (CEBA banks, in particular). ${ }^{71}$

Two factors seem to be important in the banking industry's dominance of this market. First, Visa and MasterCard by-laws require institutions issuing their cards to be depository institutions. Second, there appears to be a net regulatory benefit to issuing credit cards through a depository institution. This benefit is derived from banks' ability to export home-state consumer protection laws on credit card products (particularly usury laws) to customers in other states. This is a major reason the majority of credit card loans are originated by banks headquartered in Delaware or South Dakota, where usury laws are least restrictive. While many nonbanks issue credit cards through a bank affiliate, nonbanks can differ substantially from banking organizations in how much of their credit card portfolio is held within the banking system and therefore subject to bank capital regulations. The past operations of Sears National Bank and its parent, Sears Roebuck Corporation, provide a useful illustration of how a primarily nonbank firm structured its credit card operations to take advantage of the benefits of being a bank while avoiding some of the associated regulatory burdens. ${ }^{72}$ Sears National Bank originated MasterCard credit cards providing the interest rate advantage of banking and the ability to use the MasterCard logo and system but each night the loan balances were transferred to the parent corporation to avoid bank regulatory burdens. At any given moment, Sears National Bank's credit card balances were negligible, despite the fact that Sears Roebuck Corporation managed a $\$ 30$ billion credit card portfolio.

\footnotetext{
${ }^{71}$ CEBA banks are limited purpose institutions established under the Competitive Equality in Banking Act of 1987.

${ }^{72}$ Sears sold its credit card portfolio to Citigroup in 2003 and no longer plays a major role in the credit card industry. However, the Sears example may be illustrative of actions potentially taken by other nonbank players in the credit card market.
} 
It is important to note that nonbanks differ in the extent to which they shift credit card loans to the nonbank parent. For example, American Express manages approximately 47 percent of its credit card portfolio outside of the banking system, while Morgan Stanley manages approximately only 6 percent of its credit card portfolio outside of the banking system. ${ }^{73}$

Banks do not enjoy any obvious informational or maturity-transformational advantages in credit card lending relative to nonbanks. Therefore, if the costs associated with regulatory capital requirements and other regulatory burdens at banks are greater than the benefits, we would expect to see credit card exposures being increasingly held by nonbanks. However, Citigroup's recent acquisition of the Sears credit card portfolio does not support this view, since the acquisition transferred credit card assets from a nonbank to a banking organization. Moreover, as noted above, many nonbank companies hold credit card assets in CEBA banks when they could choose to operate outside the banking system. This provides some evidence that the benefits of issuing credit cards at banks outweigh any burden of existing bank capital regulations.

Now consider the effect of Basel II on a nonbank company with a CCSB subsidiary. Suppose the CCSB subsidiary continues to operate under the Basel I-based rules. In this case, there will be no direct effect of Basel II on the company. However, if Basel II generates a higher, binding capital requirement on A-IRB banks, then nonbank issuers could potentially benefit in the same way as bank issuers that continue under Basel I-based rules.

Now suppose that the CCSB subsidiary of a nonbank credit card issuer opts in to the A-IRB. Our estimates indicate that the CCSB subsidiary could potentially face a substantially higher regulatory capital requirement than CCSBs operating under Basel I-based rules. However, even in this case, a nonbank company can effectively avoid the constraint by transferring more of its credit card assets to the nonbank parent.

\footnotetext{
${ }^{73}$ The data are for June 30, 2004, and are based on a comparison of SEC filings with Call Report data. These figures likely overstate the percentage of credit card receivables held outside of banks, since the Call Report definition for credit card loans excludes loans to businesses while this need not be true of SEC filings.
} 
To summarize, under current rules, banks issuing and holding credit card exposures do not appear to be disadvantaged relative to nonbanks, despite the existence of regulatory capital requirements for banks. Nonbanks are issuing the majority of their credit card loans through CCSBs. There are currently no mandatory A-IRB banks among the CCSB subsidiaries of nonbank companies. However, even if a banking subsidiary of a nonbank opted in, any potential competitive effects of Basel II on nonbanks should be similar to the effects on bank credit card issuers that continue to operate under Basel I-based rules. We note one possible exception to this conclusion. We have argued that subjective supervisory action would likely raise capital requirements for any bank with a very poor performing CC-ABS portfolio. Therefore, banks operating under Basel I-based rules may not be advantaged relative to A-IRB banks despite the presence of a mechanism to bring securitized assets on balance sheet in Basel II. Assets held outside the bank regulatory umbrella may not be subject to this type of subjective supervisory action. Therefore, during times of extreme stress in CC-ABS portfolios, nonbanks may have an advantage over all banks.

\section{Implications}

In this section we consider the possible effects of moving from a nonbinding to a binding capital requirement on individual banks as well as the credit card industry as a whole. We also list some probable reactions to the change in capital rules. ${ }^{74}$ Finally we consider how potential competitive effects could vary depending upon the state of the economy.

We begin by restating our finding that required capital levels are expected to be higher for credit card portfolios under the A-IRB framework than under the current Basel I-based rules. Therefore, we conclude that A-IRB banks will not be advantaged by the change in rules and could be disadvantaged if regulatory capital requirements become binding. We also note that the expected increase in capital requirements is substantially larger for total capital than for tier 1 capital. Equity is the most important

\footnotetext{
${ }^{74}$ The federal banking agencies are considering revisions to the current capital rules that would mitigate any competitive distortions created by the Basel II A-IRB framework (see Greenspan, 2005). Our analysis compares the
} 
component of tier 1 capital, while subordinated debt is typically the most important component of tier 2 capital. Subordinated debt is a relatively cheap form of financing compared to equity, so an increase in total capital requirements that can be met with tier 2 capital would likely have more modest competitive effects than if the shortfall were in tier 1 capital. This is particularly true for CCSBs that rely heavily on market-based funding rather than core deposits. The difference in cost of raising funds through subordinated debt versus securitization should be relatively modest.

According to our estimates, it is unlikely that most CCSBs would have to make substantial additions to tier 1 capital under the A-IRB, because the estimated increase in tier 1 requirements under the A-IRB are relatively modest compared to the very large tier 1 buffers held by these banks. Those large buffers are held because the market focuses on equity capital and managed assets, which lead to market capital requirements that far exceed the Basel I-based requirements. Since CCSBs' holdings of tier 1 capital would continue to exceed the higher regulatory minimum under A-IRB by a large buffer, it is unlikely that there would be any pressure to add to the tier 1 capital levels that the market currently requires.

While CCSBs would have to increase total capital under A-IRB, we believe any competitive disadvantages from higher total capital requirements would likely be modest, since the requirement can be met with subordinated debt and securitization, which are relatively cheap forms of financing compared to equity.

Although we don't believe the increase in tier I and total capital requirements under A-IRB creates competitive effects on the industry, we do see some reactions to the changes in capital requirements as more probable. These include the following:

1. The increased capital requirements for credit card portfolios under the proposed Basel II framework will deter some opt-in banks from adopting the Basel II capital standards. This effect will be greatest for banks with a large proportion of their assets in credit cards (particularly for

proposed A-IRB guidelines to the current Basel I-based rules without considering any changes to the current capital guidelines. 
opt-in independent monoline credit card banks). We believe the disincentive to opt in will be much less for diversified banks with a CCSB subsidiary for two reasons. First, credit card portfolios represent a relatively small percentage of these banks' risk-weighted assets. Second, the A-IRB will likely reduce requirements on most non-credit-card bank portfolios, which will offset the higher capital requirement on these banks' credit card portfolios.

2. Capital-constrained (either tier 1 or total capital) A-IRB banks will increase their level of securitization of credit card receivables. Although the proposed Basel II A-IRB framework adds a potential capital charge for the investor's share of CC-ABS, these capital charges are lower than if these assets were held on balance sheet (until the highly unlikely event of hitting the 100 percent CCF threshold, at which time the capital charges are equalized). Banks that are capitalconstrained can reduce their risk-weighted assets by shifting assets off of the balance sheet, e.g., via securitization. We note that some banks already securitize a very high proportion of their managed credit card portfolio and so this option may not be available to them.

3. A-IRB banks that are faced with binding total regulatory capital requirements, but not binding tier 1 regulatory capital requirements, will likely increase their use of subordinated debt instruments that qualify as tier 2 capital.

4. Tier 1 capital-constrained A-IRB banks that currently hold reserves of less than one year's worth of expected losses will likely increase their reserves. Under the proposed Basel II A-IRB framework banks must hold capital (50 percent tier 1 and 50 percent tier 2) for any shortfall between one year of expected losses and the allowance for loan and lease losses. If CCSBs operating under the A-IRB choose to hold reserves equal to EL, our estimates suggest a minimal change in their tier 1 ratio. Given the expense of tier 1 capital relative to reserves, if faced with the choice of raising additional tier 1 capital or increasing reserves, a bank would likely increase reserves.

5. CC-ABS deal structures will likely be re-engineered to reduce deal-specific excess spread trapping points, thereby reducing potential capital charges associated with CC-ABS. As currently 
structured, excess-spread performance triggers lead to the funding of cash collateral accounts that provide a form of protection to investors in CC-ABS deals. Hitting these excess-spread performance triggers is unambiguously more expensive for banks under the proposed A-IRB framework than under current capital rules, so banks have an incentive to reduce these triggers. Investors in CC-ABS have a stake in ensuring the continued viability of the CC-ABS servicer (typically the bank), so investors may also favor a reduction in these triggers. Furthermore, we believe that it may be possible to substitute another form of credit enhancement or other protection so that investors in $\mathrm{CC}-\mathrm{ABS}$ are exposed to no additional risk despite lower trapping points relative to current deal structures.

6. Under stress, there would be an increased incentive for an A-IRB bank to engage in informal recourse to support its CC-ABS than for a bank operating under Basel I-based rules. The penalty for engaging in informal recourse is that a bank must bring its CC-ABS portfolio back on balance sheet. Under Basel II A-IRB rules, a bank must progressively bring CC-ABS deals back on balance sheet as performance deteriorates. This implies that A-IRB banks will face lower de facto penalties for engaging in informal recourse to support their CC-ABS than banks facing Basel I-based capital rules.

7. Nonbank competitors with banking subsidiaries that opt in to the A-IRB framework will be more likely to transfer credit cards from the banking subsidiary to the parent organization to avoid capital requirements. In particular, nonbank competitors will be more likely to issue CC-ABS at the parent level rather than at the bank level.

Under normal economic environments, we believe that the likely competitive effects will be modest. The credit card industry has continued to consolidate in recent years, and the share of industry assets held by the largest banks has been increasing. This trend has continued even as the likely shape of Basel II-based rules has become clear. This continued movement toward consolidation of credit card 
portfolios in likely A-IRB banks creates a revealed preference argument that the advantages to scale outweigh any competitive disadvantages associated with Basel II-based A-IRB rules.

Nevertheless, we recognize that many of the probable reactions to the A-IRB framework outlined above will have some costs and therefore provide some competitive advantages to banks with large credit card portfolios that continue to operate under Basel I-based rules. However, we have not observed any migration of credit card portfolios to these banks (in fact, we have observed the opposite), so it is reasonable to conclude that any competitive advantage will, under normal circumstances, be small.

Clearly, there is a potential for a substantial disadvantage for A-IRB bank credit card portfolios when those portfolios are under stress. An economic environment that combined high interest rates with high levels of unemployment (e.g., the early 1980s) could lead to industry-wide deterioration in CC-ABS excess-spread levels. If industry-wide levels of excess spread were to fall, A-IRB banks would face increasing numerical regulatory capital requirements that would not be applicable to non-A-IRB competitors. However, we believe the difference in numerical minimum capital requirements may overstate the difference in effective capital requirements these banks would face. It is highly likely that any bank with credit card portfolios undergoing similar stress would see supervisory requirements that would substantially exceed the numerical regulatory capital minimums.

\section{Conclusions}

This paper has looked at three types of potential competitive effects of Basel II proposals for minimum regulatory capital requirements on credit card exposures.

First, we examined whether the competitive position of community and regional banks would be harmed with the introduction of a bifurcated regulatory capital system in the U.S., in which some large banks operate under the A-IRB rules and community and most regional banks operate under Basel Ibased rules. In particular, some community bankers and analysts have expressed concerns that A-IRB banks would face substantially lower capital requirements than Basel I banks. We found that this concern is unwarranted with respect to the credit card portfolio, since credit cards are not an important product for community or most regional banks in terms of assets, revenue, or income, and our analysis of A-IRB 
capital requirements for credit cards indicates that the A-IRB is likely to raise, not lower, regulatory capital requirements for a typical A-IRB credit card specialty bank (CCSB).

Second, we examined whether the A-IRB would have a competitive effect on banks that are substantial issuers of credit card loans and that adopt A-IRB vs. issuers that remain under Basel I-based rules. Our analysis indicated that capital at CCSBs is far in excess of current regulatory requirements, as well as far higher than capital ratios at other banks, even after controlling for factors affecting the demand for capital. Indeed, capital positions at CCSBs appear to be driven by market pressures to maintain an adequate capital-to-managed-assets ratio rather than by regulatory requirements. Thus, current regulatory capital standards do not appear to be binding at CCSBs.

In most circumstances, CCSBs will operate with a zero credit conversion factor (CCF) for securitized credit card receivables. Under those circumstances, our estimates indicate that regulatory requirements for total capital would rise much more than the tier 1 requirements. While capital levels at CCSBs would remain above regulatory requirements, the buffer for total risk-based capital would be reduced substantially, and we cannot rule out that the total capital requirement would be binding for A-IRB banks. The A-IRB's effect on tier 1 capital at CCSBs is more modest, and we think it unlikely that under normal economic conditions these banks would be required to raise additional tier 1 capital if they adopted the A-IRB. First, we believe that in most cases the level of tier 1 capital will remain sufficiently above the regulatory requirements that market capital requirements will continue to determine the actual level of tier 1 capital. Second, even CCSBs operating under the A-IRB that faced pressure to raise the tier 1 ratio would likely satisfy this by raising reserves, thereby reducing their reserve shortfall, which is deducted from A-IRB tier 1 capital. Thus, to meet the higher minimum total capital requirement under A-IRB, it is likely CCSBs would either raise additional subordinated debt or increase their rate of securitization. Either of these actions has relatively modest cost implications for banks operating under the A-IRB.

In contrast to periods of normal economic conditions, there is the possibility that credit card operations at A-IRB banks would face a significant disadvantage relative to issuers operating under Basel 
I-based rules during periods of substantial stress in credit card portfolios. Under those circumstances, the additional required capital generated by a positive $\mathrm{CCF}$ for securitized assets would be a substantial increase in the minimum capital requirement. However, we believe that this much larger requirement for credit card portfolios at A-IRB banks exaggerates the difference in the "effective" capital requirement at A-IRB and Basel I banks. In our view, banks operating under Basel I-based rules would see supervisory requirements that far exceeded the numerical minimums. In addition, the market capital requirements for credit card portfolios can also be expected to rise in periods when credit performance is poor.

Finally, we also examined the potential effect on nonbank companies that are major credit card issuers. These nonbank companies typically issue credit card loans through a CCSB but have the option to hold the credit card assets at the nonbank parent. Our analysis concludes that adoption of A-IRB will have an effect on nonbanks that is similar to its effect on banks that continue to operate under Basel Ibased rules. 


\section{Glossary}

Affiliated monoline credit card bank: A bank for which credit cards account for 50 percent or more of its managed loan portfolio and which is affiliated with a diversified banking organization.

Asset value correlation (AVC): A measure of the correlation of losses among the assets within a given asset class (e.g., credit cards, C\&I loans, mortgage loans).

Credit card asset-backed securities (CC-ABS): Securities collateralized by credit card receivables.

Credit card specialty bank (CCSB): Either an affiliated monoline credit card bank or an independent monoline credit card bank.

Excess spread: The interest payments and other fees received on the assets in the pool of securitized assets less the interest payments made on the asset-backed securities, plus expenses, including the fees paid to service the assets. Excess spread is used to absorb losses by replacing assets in the pool; if it is not needed to absorb losses, it is either paid to the issuer or put in a reserve account (i.e., "trapped" in a reserve account). The level of excess spread that determines whether excess spread is paid to a reserve account rather than to the issuer is called the "trapping point."

Exposure at default (EAD): The credit exposure of the bank at the time of default.

Inactive accounts (aka dormant accounts): Credit cards with a zero balance and no sales activity for some defined period of time.

Independent monoline bank: A bank that is the top tier bank within a banking organization and for which credit cards account for 50 percent or more of its managed loan portfolio.

Loan equivalence (LEQ) of the open-to-buy: The ratio of expected future drawdowns of credit lines in the event of default to the amount of the open-to-buy.

Loss given default (LGD): The fraction of the exposure at default that will not be recovered following default.

Managed credit card receivables assets: On-balance-sheet credit card loans and outstanding credit card assets sold and securitized with servicing retained or with recourse or other seller-provided credit enhancements.

Monoline credit card bank: A credit card specialty bank. It can be either an affiliated monoline credit card bank or an independent monoline credit card bank.

Open-to-buy: The amount of unused credit, which equals the card's predefined limit minus outstanding balances.

Probability of default (PD): The probability that a borrower will default on the credit obligation during some specified horizon.

Qualifying revolving retail exposures (QRREs): Exposures that qualify as revolving retail exposures for the purposes of Basel II. The exposures must be revolving (i.e., customers' outstanding balances are permitted to fluctuate based on their decisions to borrow and repay, up to a limit set by the bank), 
unsecured, uncommitted, to individuals, and of low value, and they must exhibit low volatility of loss rates.

Revolvers: Consumers who carry a balance on their credit cards from one month to another.

Risk-based capital ratio (RBC): Capital to risk-weighted assets, where the risk weights are defined by Basel I standards.

Transactors: Consumers who pay off their entire balance on their credit card each month.

Trapping point: A predefined level of excess spread below which excess spread is no longer paid to the issuer but is instead held (i.e., "trapped") in escrow as a form of credit enhancement. 
Figure 1. Proposed A-IRB Minimum Regulatory Capital as a Percentage of Exposure at Default Assuming LGD of $90 \%$

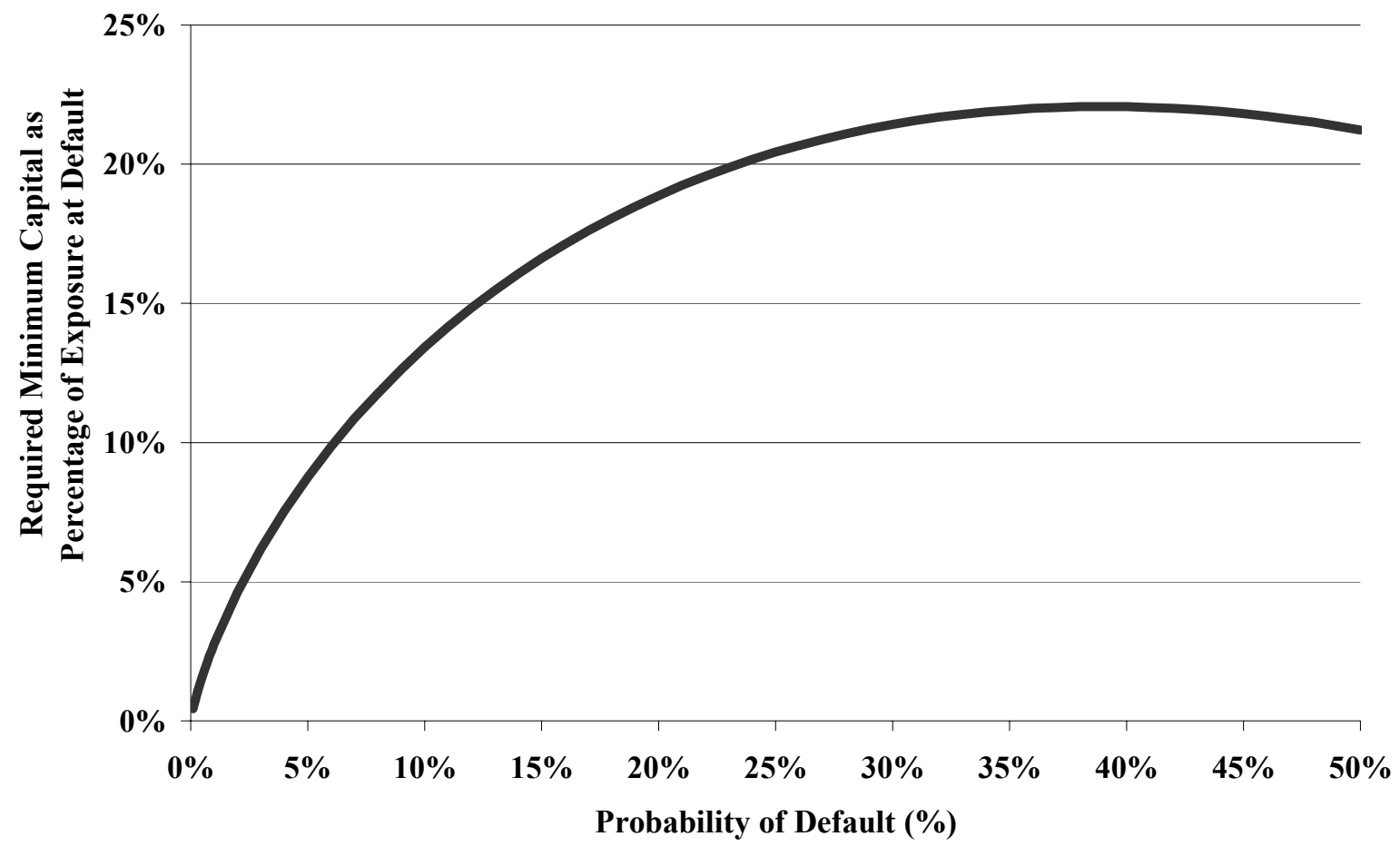




\section{Figure 2. Commercial Bank Credit Card Securitization Rates and Equity Capital Asset Ratios for Credit Card Specialty Banks (CCSBs)}

\section{Percent}

\section{Percent}

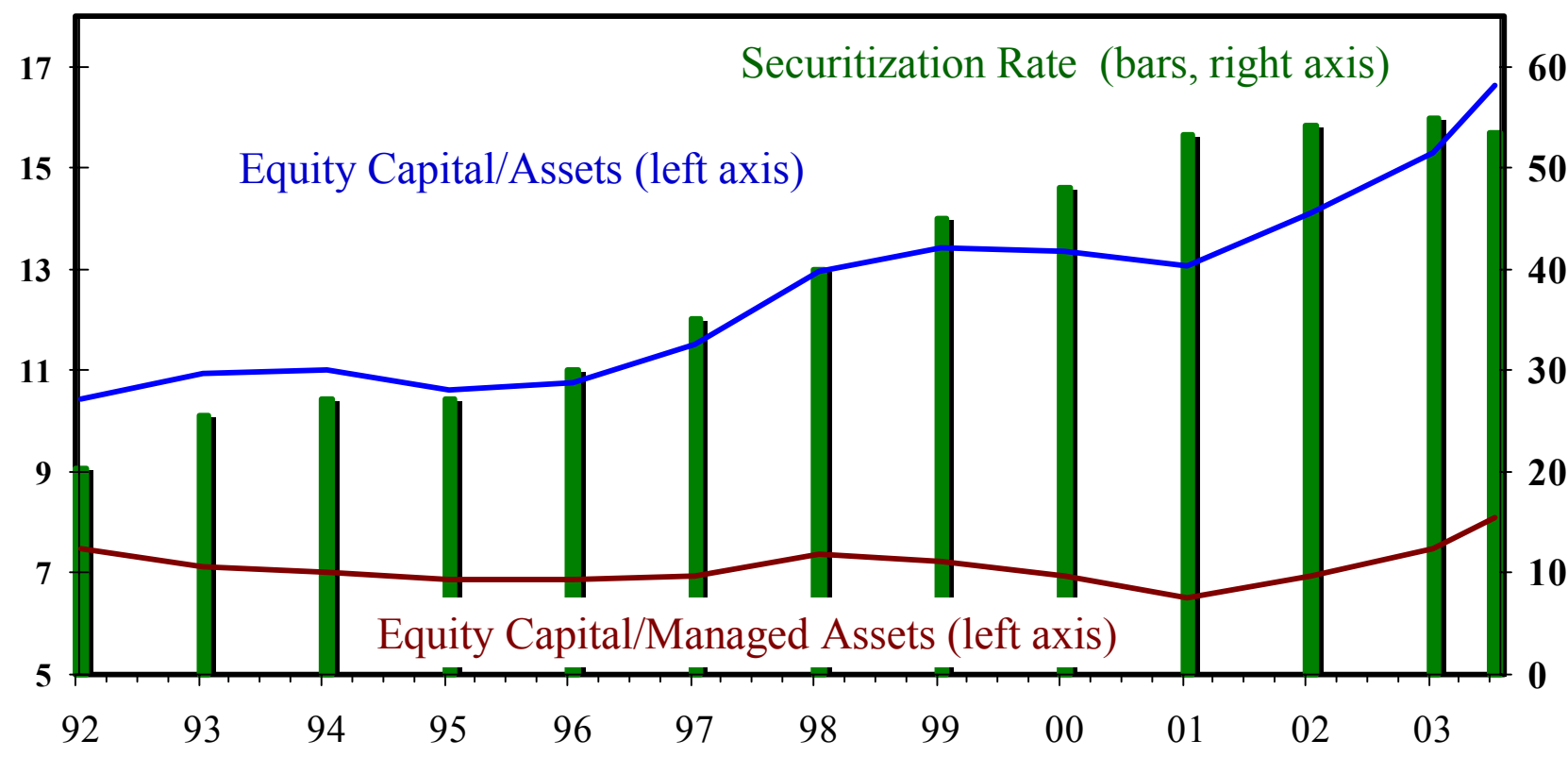

Source: Securitization data prior to 2001 are from Faulkner and Grey; all other data are from Call Reports. The capital ratios are assetweighted and managed-asset weighted averages for the CCSBs. Securitization rates are across all commercial banks. All series are Annual data as of year-end, except for final observation, which is as of June 30, 2004. smoothed by a moving average of the three most recent time periods. 
Figure 3. Charge-off Rates at Credit Card Specialty Banks (CCSBs)

CCSB charge-off rates over time

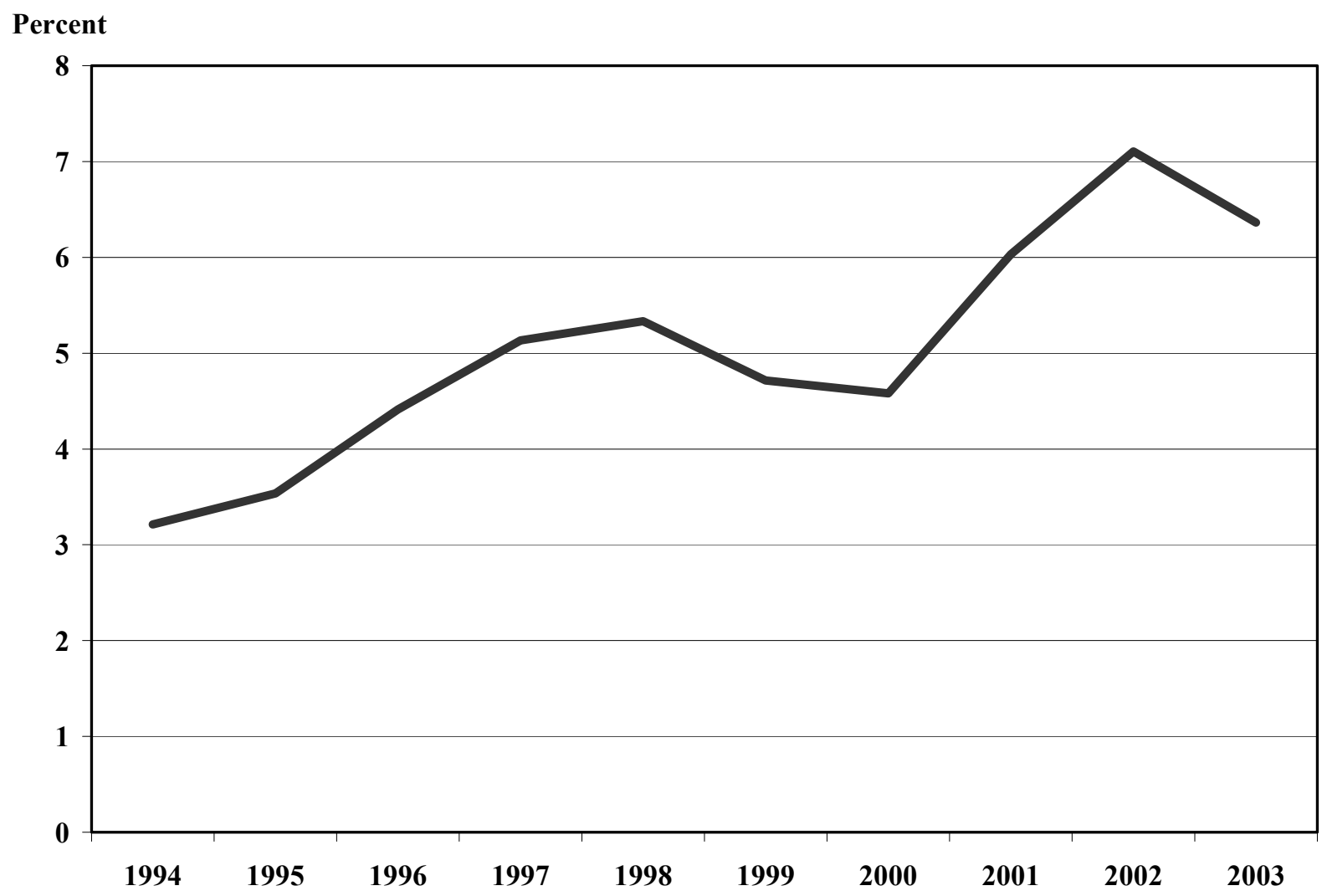

Source: Carlson and Perli (2003). 
Table 1: Importance of Credit Cards for Selected Financial Institutions, as of June 2004

\begin{tabular}{lccccc} 
Holding Company & $\begin{array}{c}\text { Managed Credit } \\
\text { Card Loans } \\
(\$ \text { billions) }\end{array}$ & $\begin{array}{c}\text { Managed Credit } \\
\text { Card Loans as a } \\
\text { Percent of } \\
\text { Consolidated } \\
\text { Managed Loans }^{1}\end{array}$ & $\begin{array}{c}\text { Credit Card } \\
\text { Revenue as a } \\
\text { Percent of } \\
\text { Consolidated }_{\text {Revenue }^{1}}\end{array}$ & $\begin{array}{c}\text { Credit Card } \\
\text { Pretax Income as } \\
\text { a Percent of } \\
\text { Consolidated } \\
\text { Pretax Income }^{1}\end{array}$ & $\begin{array}{c}\text { Credit Card } \\
\text { Charge-offs as a } \\
\text { Percent of Total } \\
\text { Charge-offs }^{2}\end{array}$ \\
\hline \hline Citigroup Inc. & $\$ 152.30$ & $26.50 \%$ & $24.40 \%$ & $117.30 \%^{3}$ & $49.46 \%$ \\
Bank One Corp. & $\$ 75.70$ & $37.80 \%$ & $44.10 \%$ & $56.10 \%$ & $54.46 \%$ \\
Bank of America Corp. & $\$ 53.10$ & $10.70 \%$ & $15.00 \%$ & $11.00 \%$ & $73.49 \%$ \\
J.P. Morgan Chase \& Co. & $\$ 50.30$ & $19.60 \%$ & $17.50 \%$ & $9.70 \%$ & $63.01 \%$ \\
\hline
\end{tabular}

${ }^{1}$ Based on SEC filings for second quarter 2004, annualized. Managed credit card loans are on-balance-sheet credit card loans plus outstanding credit card assets sold and securitized with servicing retained or with recourse or other seller-provided credit enhancements.

${ }^{2}$ Based on FRY-9C filings. Charge-off data are for on-balance-sheet credit card loans.

${ }^{3}$ Citigroup experienced a large loss associated with its settlement in the WorldCom case that generated a net loss for the company after netting out income from its credit card portfolio. Pretax income from credit card operations as a percent of pretax consolidated income averaged 21 percent for Citigroup over the prior three years.

Note, these data are holding company level data, whereas the data in Table 2 are bank level data. 
Table 2: Selected Financial Data for All Credit Card Specialty Banks (CCSBs), June 2004

\begin{tabular}{|c|c|c|c|c|c|}
\hline Bank & $\begin{array}{c}\text { Total Managed } \\
\text { Credit Card } \\
\text { Receivables } \\
\text { (\$ billions) } \\
\end{array}$ & $\begin{array}{l}\text { Off-Balance- } \\
\text { Sheet Credit } \\
\text { Card } \\
\text { Receivables } \\
\text { (Percent) }\end{array}$ & $\begin{array}{l}\text { Tier 1 Capital- } \\
\text { to-Total- } \\
\text { Assets Ratio } \\
\text { (Percent) }\end{array}$ & $\begin{array}{c}\text { Equity-Capital- } \\
\text { to-Total-Assets } \\
\text { Ratio } \\
\text { (Percent) } \\
\end{array}$ & $\begin{array}{c}\text { Equity-Capital- } \\
\text { to-Managed- } \\
\text { Assets Ratio } \\
\text { (Percent) }\end{array}$ \\
\hline MBNA America Bank NA * & $\$ 99.444$ & 81.49 & 19.49 & 20.18 & 8.37 \\
\hline Citibank SD NA * & $\$ 91.056$ & 54.83 & 13.49 & 20.62 & 10.61 \\
\hline Capital One Bank * & $\$ 49.670$ & 71.02 & 11.60 & 12.12 & 5.18 \\
\hline Chase Manhattan Bank USA NA * & $\$ 49.592$ & 66.81 & 13.29 & 12.75 & 7.16 \\
\hline Discover Bank $*$ & $\$ 44.209$ & 63.39 & 17.88 & 16.96 & 6.53 \\
\hline Citibank NV NA * & $\$ 39.208$ & 61.14 & 13.76 & 18.40 & 8.24 \\
\hline Bank of America NA USA * & $\$ 37.815$ & 1.32 & 9.74 & 9.60 & 9.48 \\
\hline Bank One DE NA * & $\$ 24.088$ & 47.31 & 14.65 & 19.86 & 11.99 \\
\hline American Express Centurion Bank * & $\$ 23.949$ & 58.52 & 11.06 & 11.30 & 5.65 \\
\hline Providian NB * & $\$ 16.964$ & 59.41 & 25.31 & 24.79 & 13.85 \\
\hline Fleet Bank RI NA * & $\$ 15.709$ & 59.20 & 22.99 & 33.04 & 15.84 \\
\hline Monogram Credit Card Bank * & $\$ 14.436$ & 78.44 & 16.08 & 21.50 & 5.32 \\
\hline USAA Savings Bank & $\$ 6.112$ & 0.00 & 32.52 & 31.09 & 31.09 \\
\hline World Financial Network NB & $\$ 3.207$ & 93.88 & 55.17 & 58.24 & 9.89 \\
\hline Juniper BK & $\$ 1.378$ & 84.39 & 10.89 & 15.08 & 4.12 \\
\hline Wells Fargo Financial NB * & $\$ 0.873$ & 0.00 & 13.11 & 12.65 & 12.65 \\
\hline World's Foremost Bank & $\$ 0.872$ & 90.64 & 34.56 & 31.82 & 5.75 \\
\hline Wells Fargo Financial Bank & $\$ 0.870$ & 0.00 & 20.39 & 19.87 & 19.87 \\
\hline Cross Country Bank & $\$ 0.859$ & 0.00 & 52.78 & 54.02 & 54.02 \\
\hline 1st Financial Bank USA & $\$ 0.546$ & 86.77 & 20.11 & 21.46 & 6.74 \\
\hline Chevron Credit Bank NA & $\$ 0.543$ & 100.00 & 26.02 & 34.21 & 7.94 \\
\hline Merrick BC & $\$ 0.505$ & 0.00 & 21.52 & 20.12 & 20.12 \\
\hline Bankfirst & $\$ 0.439$ & 0.00 & 24.39 & 24.89 & 24.89 \\
\hline First Premier Bank & $\$ 0.313$ & 0.00 & 23.96 & 24.51 & 24.51 \\
\hline Infibank NA & $\$ 0.285$ & 77.19 & 21.60 & 23.57 & 7.86 \\
\hline First NB of Marin & $\$ 0.228$ & 0.00 & 30.32 & 30.05 & 30.05 \\
\hline First-Citizens Bank NA & $\$ 0.197$ & 0.00 & 24.99 & 24.83 & 24.83 \\
\hline UMB USA NA & $\$ 0.116$ & 0.00 & 21.48 & 21.46 & 21.46 \\
\hline Retailers NB & $\$ 0.113$ & 0.00 & 45.78 & 46.17 & 46.17 \\
\hline TCM BK NA & $\$ 0.084$ & 0.00 & 10.13 & 11.80 & 11.80 \\
\hline BB\&T Bankcard Corp & $\$ 0.084$ & 0.00 & 24.06 & 31.81 & 31.81 \\
\hline 5 Star Bank Co Ind Bk & $\$ 0.079$ & 0.00 & 15.26 & 15.34 & 15.34 \\
\hline Direct Merchant Credit Card Bank NA & $\$ 0.070$ & 0.00 & 70.83 & 72.79 & 72.79 \\
\hline Credicard NB & $\$ 0.007$ & 0.00 & 28.79 & 33.03 & 33.03 \\
\hline RBC Centura Card Bank & $\$ 0.004$ & 0.00 & 93.19 & 92.37 & 92.37 \\
\hline Commerce Bank NA & $\$ 0.003$ & 0.00 & 86.04 & 85.33 & 85.33 \\
\hline Belk NB & $\$ 0.002$ & 0.00 & 50.53 & 30.59 & 30.59 \\
\hline Cedar Hill NB & $\$ 0.001$ & 0.00 & 64.85 & 65.45 & 65.45 \\
\hline Total of all CCSBs & $\$ 523.930$ & 59.97 & 15.67 & 17.71 & 9.03 \\
\hline
\end{tabular}

Managed credit card loans are on-balance-sheet credit card loans plus outstanding credit card assets sold and securitized with servicing retained or with recourse or other seller-provided credit enhancements.

Off-balance-sheet credit cards are defined as securitized credit cards less the seller's interest.

The ratios for the total of all CCSBs are calculated as the value of the numerator for all CCSBs divided by the value of the denominator for all CCSBs. This is equivalent to a weighted average of the ratios for the individual banks, where the weight is the bank's share of the value of the denominator for all CCSBs.

Note, these data are bank level data, whereas the data in Table 1 are holding company level data.

* Institution is included in the regression analysis. 
Table 3. Difference-in-Means Test for Noncredit Card and Credit Card Specialty Banks (CCSBs)

\begin{tabular}{|c|c|c|c|c|c|c|c|}
\hline & $\begin{array}{c}\text { Noncredit Card } \\
\text { Specialty Banks } \\
(\text { No. of Obs. }=262)\end{array}$ & $\begin{array}{c}\text { Credit Card } \\
\text { Specialty Banks } \\
(\text { No. of Obs. }=13)\end{array}$ & & & $\begin{array}{c}\text { Noncredit Card } \\
\text { Specialty Banks } \\
(\text { No. of Obs. }=262)\end{array}$ & $\begin{array}{c}\text { Credit Card } \\
\text { Specialty Banks } \\
(\text { No. of Obs. }=13)\end{array}$ & \\
\hline & $\begin{array}{c}\text { Mean } \\
\text { (Standard } \\
\text { Deviation) }\end{array}$ & $\begin{array}{c}\text { Mean } \\
\text { (Standard } \\
\text { Deviation) }\end{array}$ & & & $\begin{array}{c}\text { Mean } \\
\text { (Standard } \\
\text { Deviation) }\end{array}$ & $\begin{array}{c}\text { Mean } \\
\text { (Standard } \\
\text { Deviation) }\end{array}$ & \\
\hline $\begin{array}{l}\text { Tier 1 Leverage } \\
\text { Ratio }\end{array}$ & $\begin{array}{c}0.0827 \\
(0.0175)\end{array}$ & $\begin{array}{c}0.1613 \\
(0.0477)\end{array}$ & $* * *$ & $\begin{array}{l}\text { Assets } \\
\text { (unweighted by risk) } \\
\text { (in billions } \$ \text { ) }\end{array}$ & $\begin{array}{c}10.11 \\
(32.09)\end{array}$ & $\begin{array}{c}24.12 \\
(18.26)\end{array}$ & $* *$ \\
\hline Tier 1 Capital to Assets & $\begin{array}{c}0.0801 \\
(0.0173)\end{array}$ & $\begin{array}{c}0.1568 \\
(0.0451)\end{array}$ & $* * *$ & $\begin{array}{l}\text { Managed Assets } \\
\text { (in billions \$) }\end{array}$ & $\begin{array}{c}10.22 \\
(32.81)\end{array}$ & $\begin{array}{c}47.82 \\
(38.46)\end{array}$ & $* * *$ \\
\hline $\begin{array}{l}\text { Tier } 1 \text { Capital to } \\
\text { Managed Assets }\end{array}$ & $\begin{array}{c}0.0800 \\
(0.0174)\end{array}$ & $\begin{array}{c}0.0847 \\
(0.0418)\end{array}$ & & $\begin{array}{l}\text { Risk-Weighted } \\
\text { Assets } \\
\text { (in billions \$) }\end{array}$ & $\begin{array}{c}7.93 \\
(24.74)\end{array}$ & $\begin{array}{c}25.59 \\
(19.40)\end{array}$ & $* * *$ \\
\hline $\begin{array}{l}\text { Tier } 1 \text { Capital to } \\
\text { Risk-Weighted Assets }\end{array}$ & $\begin{array}{c}0.1046 \\
(0.0230)\end{array}$ & $\begin{array}{c}0.1504 \\
(0.0427)\end{array}$ & $* * *$ & $\begin{array}{l}\text { Equity Capital } \\
\text { (in billions } \$ \text { ) }\end{array}$ & $\begin{array}{c}0.8850 \\
(2.794)\end{array}$ & $\begin{array}{c}4.12 \\
(3.42)\end{array}$ & $* * *$ \\
\hline $\begin{array}{l}\text { Equity Capital to } \\
\text { Assets }\end{array}$ & $\begin{array}{c}0.0929 \\
(0.0253)\end{array}$ & $\begin{array}{c}0.1854 \\
(0.0631)\end{array}$ & $* * *$ & $\begin{array}{l}\text { Tier 1 Capital } \\
\text { (in billions } \$ \text { ) }\end{array}$ & $\begin{array}{c}0.709 \\
(2.088)\end{array}$ & $\begin{array}{c}3.47 \\
(2.80)\end{array}$ & $* * *$ \\
\hline $\begin{array}{l}\text { Equity Capital to } \\
\text { Managed Assets }\end{array}$ & $\begin{array}{c}0.0928 \\
(0.0254)\end{array}$ & $\begin{array}{c}0.0985 \\
(0.0448)\end{array}$ & & $\begin{array}{l}\text { Total Capital } \\
\text { (=Total Risk-Based } \\
\text { Capital = Tier 1+ } \\
\text { Tier 2 Capital) } \\
\text { (in billions \$) }\end{array}$ & $\begin{array}{c}0.918 \\
(2.826)\end{array}$ & $\begin{array}{c}4.34 \\
(3.52)\end{array}$ & $* * *$ \\
\hline $\begin{array}{l}\text { Equity Capital to } \\
\text { Risk-Weighted Assets }\end{array}$ & $\begin{array}{c}0.1217 \\
(0.0351)\end{array}$ & $\begin{array}{c}0.1784 \\
(0.0621)\end{array}$ & $* * *$ & $\begin{array}{l}\text { Coefficient of } \\
\text { Variation in ROE }\end{array}$ & $\begin{array}{l}0.4705 \\
(1.904)\end{array}$ & $\begin{array}{c}0.6704 \\
(0.3658)\end{array}$ & \\
\hline $\begin{array}{l}\text { Total Capital (= Total } \\
\text { Rised-Based Capital = } \\
\text { Tier } 1+\text { Tier } 2 \text { Capital) } \\
\text { to Assets }\end{array}$ & $\begin{array}{c}0.0926 \\
(0.0174)\end{array}$ & $\begin{array}{c}0.1923 \\
(0.0517)\end{array}$ & $* * *$ & $\begin{array}{l}\text { Coefficient of } \\
\text { Variation in ROE } \\
\text { (merger-adjusted) }\end{array}$ & $\begin{array}{l}0.7505 \\
(6.967)\end{array}$ & $\begin{array}{c}0.5963 \\
(0.4684)\end{array}$ & \\
\hline $\begin{array}{l}\text { Total Capital to } \\
\text { Managed Assets }\end{array}$ & $\begin{array}{c}0.0925 \\
(0.0175)\end{array}$ & $\begin{array}{c}0.1063 \\
(0.0593)\end{array}$ & & Asset Growth & $\begin{array}{c}1.691 \\
(13.679)\end{array}$ & $\begin{array}{c}0.5871 \\
(0.6957)\end{array}$ & \\
\hline $\begin{array}{l}\text { Total Capital to Risk- } \\
\text { Weighted Assets }\end{array}$ & $\begin{array}{c}0.1206 \\
(0.0214)\end{array}$ & $\begin{array}{c}0.1847 \\
(0.0506)\end{array}$ & $* * *$ & $\begin{array}{l}\text { Asset Growth } \\
\text { (merger-adjusted) }\end{array}$ & $\begin{array}{c}1.256 \\
(13.643)\end{array}$ & $\begin{array}{c}0.4645 \\
(0.5359)\end{array}$ & \\
\hline
\end{tabular}

\footnotetext{
*** Means of the variable for noncredit card specialty banks and for credit card specialty banks are significantly different at the $99 \%$ level.

** Means of the variable for noncredit card specialty banks and for credit card specialty banks are significantly different at the $95 \%$ level.

* Means of the variable for noncredit card specialty banks and for credit card specialty banks are significantly different at the $90 \%$ level.
}

The hypothesis of equal variances could not be rejected at the $90 \%$ or better level for managed assets, risk-weighted assets, equity capital, and total capital. So for these variables the pooled test (which assumes equal variances) was used to test difference in means. The Satterthwaite test (which allows for unequal variances) was used to test the difference in means of all other variables. 


\section{Table 4a: Equity Capital Ratio Regressions}

Model 1

Model 2

Model 3

\begin{tabular}{|c|c|c|c|c|c|c|}
\hline $\begin{array}{l}\text { Dependent Variable } \\
\text { Independent Variables }\end{array}$ & \multicolumn{2}{|c|}{$\begin{array}{c}\text { Equity Capital to } \\
\text { Total Assets }\end{array}$} & \multicolumn{2}{|c|}{$\begin{array}{l}\text { Equity Capital to } \\
\text { Managed Assets }\end{array}$} & \multicolumn{2}{|c|}{$\begin{array}{c}\text { Equity Capital to } \\
\text { Risk-Weighted } \\
\text { Assets }\end{array}$} \\
\hline \multirow[t]{2}{*}{ Intercept } & 0.09041 & $* * *$ & 0.09021 & $* * *$ & 0.1196 & $* * *$ \\
\hline & $(0.00192)$ & & $(0.00190)$ & & $(0.00240)$ & \\
\hline \multirow[t]{2}{*}{ Coefficient of Variation in ROE } & 0.00373 & $* * *$ & 0.00366 & $* * *$ & 0.00506 & $* * *$ \\
\hline & $(0.00103)$ & & $(0.00105)$ & & $(0.000994)$ & \\
\hline \multirow[t]{2}{*}{ Total Assets } & -0.000252 & $* *$ & -0.000231 & $* *$ & -0.000382 & $* *$ \\
\hline & $(0.000112)$ & & $(0.000109)$ & & $(0.000149)$ & \\
\hline \multirow[t]{2}{*}{ Total Assets Squared } & 0.000000667 & $* *$ & 0.000000586 & $*$ & 0.00000105 & $*$ \\
\hline & $(0.000000328)$ & & $(0.000000316)$ & & $(0.000000444)$ & \\
\hline \multirow[t]{2}{*}{ Growth in Total Assets } & 0.00295306 & $*$ & 0.00295 & $*$ & 0.00268 & $* *$ \\
\hline & $(0.00169)$ & & $(0.00169)$ & & $(0.00154)$ & \\
\hline \multirow[t]{2}{*}{ Growth in Total Assets Squared } & -0.0000131 & $*$ & -0.0000131 & $*$ & -0.0000114 & \\
\hline & $(0.00000767)$ & & $(0.00000765)$ & & $(0.00000697)$ & \\
\hline \multirow[t]{2}{*}{ Credit Card Bank Indicator } & 0.09623 & $* * *$ & 0.00917 & & 0.06209 & $* * *$ \\
\hline & $(0.0170)$ & & $(0.0127)$ & & $(0.0164)$ & \\
\hline Adjusted $\mathrm{R}^{2}$ & 0.3944 & & 0.1057 & & 0.1741 & \\
\hline Number of Observations & 275 & & 275 & & 275 & \\
\hline
\end{tabular}

Standard errors are in parentheses. The standard errors are heteroscedasticity-consistent and calculated using the Davidson and MacKinnon (1993) adjustment of the covariance matrix of the estimated parameters, $\left(X^{\prime} X\right)^{-1}\left(X^{\prime} \hat{\Omega} X\right)\left(X^{\prime} X\right)^{-1}$ where $\hat{\Omega} \equiv \operatorname{diagonal}$ matrix with $\frac{n}{n-k} e_{t}^{2}$ on the diagonal, where $e_{t}$ is the estimated regression error, that is, $e_{t}=y_{t}-x_{t} \hat{\beta}, n=$ number of observations and $k=$ number of explanatory variables.

$* * *$ Significantly different from zero at the $99 \%$ level, $* *$ Significantly different from zero at the $95 \%$ level, $*$ Significantly different from zero at the $90 \%$ level.

Equity capital to assets is equity capital/total assets as of June 2004, where equity capital is RCFD3210 from the Call Report and total assets is RCFD2170 from the Call Report.

Equity capital to managed assets is equity capital/managed assets, where managed assets equals total assets plus outstanding credit card assets sold and securitized with servicing retained or with recourse or other seller-provided credit enhancements as of June 2004.

Equity capital to risk-weighted assets is equity capital/risk-weighted assets (RCFDA223 from the Call Report) as of June 2004.

The coefficient of variation in ROE is the standard deviation of quarterly ROE from 1992-2003 divided by mean ROE from $1992-2003$.

Total assets are total assets, unweighted by risk (RCFD2170 from the Call Report), measured in units of \$1 billion as of June 2004.

Growth in total assets is measured between year-end 2000 and year-end 2003

Credit card bank indicator is equal to 1 if the bank is a credit card specialty bank, or 0 otherwise. There are 13 credit card specialty banks in the sample. 
Table 4b: Total Capital Ratio Regressions

Model 1

Total Capital to Total Assets

Dependent Variable

Independent Variables

Intercept

Coefficient of Variation in ROE

Total Assets

Total Assets Squared

Growth in Total Assets

Growth in Total Assets Squared

Credit Card Bank Indicator

$(0.00169)$

$(0.000801)$

$-0.0000789$

(0.000092)

0.000000174

$(0.000000283)$

0.000412

(0.00170)

$-0.00000202$

(0.00000771)

\subsection{8}

Model 2

Model 3

Total Capital to

Risk-Weighted Assets

Total Capital to
Managed Assets
Managed Assets

0.09236
$(0.00172)$

$* * *$

0.1218

0.000786

(0.00192)

$(0.000803)$

0.00152

$-0.0000815$

(0.00110)

$(0.000108)$

$-0.000222$

0.000000162

(0.000082)

(0.000000329)

0.000000610

0.000499

$(0.000000262)$

(0.00168)

$-0.000550$

$-0.00000241$

(0.00148)

(0.00000764)

0.00000280

0.01498

(0.00000673)

$* * *$

(0.0143)

(0.0171)

0.06694

(0.0137)

0.2586

Adjusted R ${ }^{2}$

0.5218

0.0097

275

Number of Observations

275

275

(175

Standard errors are in parentheses. The standard errors are heteroscedasticity-consistent and calculated using the Davidson and MacKinnon (1993) adjustment of the covariance matrix of the estimated parameters, $\left(X^{\prime} X\right)^{-1}\left(X^{\prime} \hat{\Omega} X\right)\left(X^{\prime} X\right)^{-1}$ where $\hat{\Omega} \equiv$ diagonal matrix with $\frac{n}{n-k} e_{t}^{2}$ on the diagonal, where $e_{t}$ is the estimated regression error, that is, $e_{t}=y_{t}-x_{t} \hat{\beta}, n=$ number of observations and $k=$ number of explanatory variables.

$* * *$ Significantly different from zero at the $99 \%$ level, $* *$ Significantly different from zero at the $95 \%$ level, $*$ Significantly different from zero at the $90 \%$ level.

Total capital to assets is total risk-based capital/total assets as of June 2004, where total risk-based capital is RCFD3792 from the Call Report and total assets is RCFD2170 from the Call Report.

Total capital to managed assets is total capital/managed assets, where managed assets equals total assets plus outstanding credit card assets sold and securitized with servicing retained or with recourse or other seller-provided credit enhancements as of June 2004.

Total capital to risk-weighted assets is total capital/risk-weighted assets (RCFDA223 from the Call Report) as of June 2004.

The coefficient of variation in ROE is the standard deviation of quarterly ROE from 1992-2003 divided by mean ROE from $1992-2003$.

Total assets are total assets, unweighted by risk (RCFD2170 from the Call Report), measured in units of \$1 billion as of June 2004.

Growth in total assets is measured between year-end 2000 and year-end 2003.

Credit card bank indicator is equal to 1 if the bank is a credit card specialty bank, or 0 otherwise. There are 13 credit card specialty banks in the sample. 
Table 4c: Tier 1 Capital Ratio Regressions

Model 1

Model 2

Model 3

\begin{tabular}{|c|c|c|c|c|c|c|}
\hline $\begin{array}{l}\text { Dependent Variable } \\
\text { Independent Variables }\end{array}$ & \multicolumn{2}{|c|}{$\begin{array}{c}\text { Tier } 1 \text { Capital to } \\
\text { Total Assets }\end{array}$} & \multicolumn{2}{|c|}{$\begin{array}{l}\text { Tier } 1 \text { Capital to } \\
\text { Managed Assets }\end{array}$} & \multicolumn{2}{|c|}{$\begin{array}{c}\text { Tier 1 Capital to } \\
\text { Risk-Weighted } \\
\text { Assets } \\
\end{array}$} \\
\hline \multirow[t]{2}{*}{ Intercept } & 0.08169 & $* * *$ & 0.08146 & $* * *$ & 0.1077 & $* * *$ \\
\hline & $(0.00163)$ & & $(0.00163)$ & & $(0.00194)$ & \\
\hline \multirow[t]{2}{*}{ Coefficient of Variation in ROE } & 0.000684 & & 0.000639 & & 0.00133 & \\
\hline & $(0.000786)$ & & $(0.000786)$ & & $(0.00107)$ & \\
\hline \multirow[t]{2}{*}{ Total Assets } & -0.000354 & $* * *$ & -0.000340 & $* * *$ & -0.000521 & $* * *$ \\
\hline & $(0.000079)$ & & $(0.000081)$ & & $(0.000091)$ & \\
\hline \multirow[t]{2}{*}{ Total Assets Squared } & 0.000000912 & $* * *$ & 0.000000857 & $* * *$ & 0.00000139 & $* * *$ \\
\hline & $(0.000000254)$ & & $(0.000000253)$ & & $(0.000000299)$ & \\
\hline \multirow[t]{2}{*}{ Growth in Total Assets } & 0.000677 & & 0.000764 & & -0.000193 & \\
\hline & $(0.00163)$ & & $(0.000161)$ & & $(0.00146)$ & \\
\hline \multirow[t]{2}{*}{ Growth in Total Assets Squared } & -0.00000289 & & -0.00000330 & & 0.00000157 & \\
\hline & $(0.00000740)$ & & $(0.00000732)$ & & $(0.00000662)$ & \\
\hline \multirow[t]{2}{*}{ Credit Card Bank Indicator } & 0.08195 & $* * *$ & 0.00978 & & 0.05327 & $* * *$ \\
\hline & $(0.0117)$ & & $(0.0117)$ & & $(0.0107)$ & \\
\hline Adjusted $\mathrm{R}^{2}$ & 0.4467 & & 0.0537 & & 0.2056 & \\
\hline Number of Observations & 275 & & 275 & & 275 & \\
\hline
\end{tabular}

Standard errors are in parentheses. The standard errors are heteroscedasticity-consistent and calculated using the Davidson and MacKinnon (1993) adjustment of the covariance matrix of the estimated parameters, $\left(X^{\prime} X\right)^{-1}\left(X^{\prime} \hat{\Omega} X\right)\left(X^{\prime} X\right)^{-1}$ where $\hat{\Omega} \equiv \operatorname{diagonal}$ matrix with $\frac{n}{n-k} e_{t}^{2}$ on the diagonal, where $e_{t}$ is the estimated regression error, that is, $e_{t}=y_{t}-x_{t} \hat{\beta}, n=$ number of observations and $k=$ number of explanatory variables.

$* * *$ Significantly different from zero at the $99 \%$ level, ** Significantly different from zero at the $95 \%$ level, * Significantly different from zero at the $90 \%$ level.

Tier 1 capital to assets is tier 1 capital/total assets as of June 2004, where tier 1 capital is RCFD8274 from the Call Report and total assets is RCFD2170 from the Call Report.

Tier 1 capital to managed assets is tier 1 capital/managed assets, where managed assets equals total assets plus outstanding credit card assets sold and securitized with servicing retained or with recourse or other seller-provided credit enhancements as of June 2004.

Tier 1 capital to risk-weighted assets is tier 1 capital/risk-weighted assets (RCFDA223 from the Call Report) as of June 2004.

The coefficient of variation in ROE is the standard deviation of quarterly ROE from 1992-2003 divided by mean ROE from $1992-2003$.

Total assets are total assets, unweighted by risk (RCFD2170 from the Call Report), measured in units of \$1 billion as of June 2004.

Growth in total assets is measured between year-end 2000 and year-end 2003.

Credit card bank indicator is equal to 1 if the bank is a credit card specialty bank, or 0 otherwise. There are 13 credit card specialty banks in the sample. 
Table 5: Change in Credit Card Specialty Banks' Required Capital from a Shift from Basel I-Based Rules to Basel II A-IRB Rules

\section{Panel A. Change in Required Total Capital}

No adjustment for eligible reserves With adjustment for eligible reserves at

$\begin{array}{lrr}\text { Average } & 44.3 \% & 23.6 \% \\ \text { Min } & & \\ \text { Max } & 19.1 \% & 6.7 \% \\ & 67.0 \% & 32.2 \%\end{array}$

\section{Panel B. Change in Required Tier 1Capital}

No shortfall adjustment

$$
2.2 \%
$$

$-5.4 \%$

$14.8 \%$
With adjustment for shortfall at Credit card specialty banks
$13.2 \%$
$-1.7 \%$
$25.8 \%$ 
Table 6: Hypothetical Example of Impact of A-IRB Capital Requirement

\begin{tabular}{|l|l|}
\hline \multicolumn{2}{|c|}{ Panel A. Adjustment for 15 Percent Credit Conversion Factor (CCF) for Hypothetical Bank } \\
\hline Owned credit card assets & $\$ 39.3$ million \\
\hline Securitized credit card assets & $\$ 60.7$ million \\
\hline $\begin{array}{l}\text { Addition to credit card assets against which bank must } \\
\text { hold capital due to trigger of 15\% CCF }\end{array}$ & $\$ 9.1$ million $(=15 \% \times \$ 60.7$ million $)$ \\
\hline $\begin{array}{l}\text { Growth in credit card assets against which capital must } \\
\text { be held with } 15 \% \text { CCF }\end{array}$ & $23.2 \%(=\$ 9.1$ million $/ \$ 39.3$ million $)$ \\
\hline
\end{tabular}

Panel B. Effect of A-IRB and 15 Percent Conversion Factor on Total Risk-Based Capital for Hypothetical Average Credit Card Bank

\begin{tabular}{|c|c|c|c|c|c|}
\hline & \multirow[b]{2}{*}{$\begin{array}{c}\text { Capital } \\
\text { Level }\end{array}$} & \multicolumn{2}{|c|}{$\begin{array}{c}\text { Using low-side estimate of } \\
23.6 \% \text { increase in } \\
\text { required total capital under A-IRB } \\
\text { relative to Basel I } \\
\end{array}$} & \multicolumn{2}{|c|}{$\begin{array}{c}\text { Using high-side estimate of } \\
44.3 \% \text { increase in } \\
\text { required total capital under A-IRB } \\
\text { relative to Basel I } \\
\end{array}$} \\
\hline & & $\begin{array}{c}\text { Risk-Weighted } \\
\text { Assets }\end{array}$ & $\begin{array}{l}\text { Total-Capital-to- } \\
\text { Risk-Weighted- } \\
\text { Asset Ratio } \\
\end{array}$ & $\begin{array}{c}\text { Risk-Weighted } \\
\text { Assets }\end{array}$ & $\begin{array}{c}\text { Total- Capital- } \\
\text { to-Risk-Weighted- } \\
\text { Asset Ratio } \\
\end{array}$ \\
\hline Basel I $^{1}$ & \$ 7.3 million & \$ 39.3 million & $18.5 \%$ & \$ 39.3 million & $18.5 \%$ \\
\hline A-IRB with zero $C_{C F}^{2}$ & \$ 7.3 million & \$ 48.6 million & $14.9 \%$ & \$ 56.7 million & $12.8 \%$ \\
\hline A-IRB with 15 percent $C C^{3}$ & \$ 7.3 million & \$ 59.8 million & $12.1 \%$ & \$ 69.8 million & $10.4 \%$ \\
\hline
\end{tabular}

Panel C. Effect of A-IRB and 15 Percent Conversion Factor on Tier 1 Risk-Based Capital for Hypothetical Average Credit Card Bank

\begin{tabular}{|c|c|c|c|c|c|}
\hline & \multirow[b]{2}{*}{$\begin{array}{c}\text { Tier } 1 \text { Capital } \\
\text { Level }\end{array}$} & \multicolumn{2}{|c|}{$\begin{array}{c}\text { Using low-side estimate of } \\
2.2 \% \text { increase in } \\
\text { required capital under A-IRB relative } \\
\text { to Basel I } \\
\end{array}$} & \multicolumn{2}{|c|}{$\begin{array}{c}\text { Using high-side estimate of } \\
13.2 \% \text { increase in } \\
\text { required capital under A-IRB relative to } \\
\text { Basel I }\end{array}$} \\
\hline & & $\begin{array}{c}\text { Risk-Weighted } \\
\text { Assets }\end{array}$ & $\begin{array}{l}\text { Tier } 1 \text { Capital-to- } \\
\text { Risk-Weighted- } \\
\text { Asset Ratio } \\
\end{array}$ & $\begin{array}{c}\text { Risk-Weighted } \\
\text { Assets }\end{array}$ & $\begin{array}{l}\text { Tier } 1 \text { Capital- } \\
\text { to-Risk-Weighted- } \\
\text { Asset Ratio } \\
\end{array}$ \\
\hline Basel I $^{1}$ & \$ 5.9 million & \$ 39.3 million & $15.0 \%$ & \$ 39.3 million & $15.0 \%$ \\
\hline A-IRB with zero $C_{C F}^{2}$ & \$ 5.9 million & $\$ 40.2$ million & $14.7 \%$ & \$ 44.5 million & $13.3 \%$ \\
\hline A-IRB with 15 percent $C C F^{3}$ & \$ 5.9 million & \$ 49.5 million & $11.9 \%$ & \$ 54.8 million & $10.8 \%$ \\
\hline
\end{tabular}

${ }^{1}$ The average total-capital-to-risk-weighted-asset ratio in our sample of credit card banks is 18.47 percent. Applying this to our hypothetical bank's owned asset level (i.e., on-balance-sheet assets), which is \$39.3 million, yields a total capital level of \$7.26 million. The average tier 1 capital-to-risk-weighted-asset ratio in our sample of credit card banks is 15.04 percent. Applying this to our hypothetical bank's owned asset level yields a tier 1 capital level of \$5.91 million.

${ }^{2}$ Based on our estimates reported in Table 5, depending on whether an adjustment is made for eligible reserves, the A-IRB might generate as low as a 23.6 percent increase in required total capital relative to Basel I levels and as high as a 44.3 percent increase in required total capital relative to Basel I levels. This can be thought of as a rise of 23.6 percent (or 44.3 percent) in the denominator of the regulatory total capital ratio. Using a 23.6 percent increase in required total capital and applying this to the hypothetical bank yields an increase in assets to $\$ 48.6$ million, which implies a decrease in the total-capital-to-asset ratio to 14.9 percent. Using a 44.3 percent increase in required total capital and applying this to the hypothetical bank yields an increase in assets to $\$ 56.7$ million, which implies a decrease in the total-capital-to-asset ratio to 12.8 percent. Similar calculations are done for the tier 1 capital ratios.

${ }^{3}$ As shown in the top panel, a trigger of the 15 percent CCF would imply a 23.2 percent increase in assets against which capital must be held. Applying this to the hypothetical bank and using a 23.6 percent increase in required total capital under A-IRB relative to Basel I yields an increase in assets to $\$ 59.8$ million, which implies a decrease in the capital-to-risk-weighted-asset ratio to 12.1 percent. Applying this to the hypothetical bank and using a 44.3 percent increase in required total capital under A-IRB relative to Basel I yields an increase in assets to $\$ 69.8$ million, which implies a decrease in the capital-to-risk-weighted-asset ratio to 10.4 percent. Similar calculations are done for the tier 1 capital ratios. 


\section{Appendix 1: The Mechanics of CC-ABS ${ }^{75}$}

This appendix discusses the mechanics of credit card asset-backed securities (CC-ABS) and their implications for regulatory capital.

CC-ABS begin with a credit card issuer selling a group of receivables from credit card accounts into a bankruptcy-remote trust (a special-purpose entity) that functions as the issuer of securities. The seller (we will use the term "seller" and "bank" interchangeably, although we recognize that not all issuers of CC-ABS are banks) remains the owner of the credit card accounts but transfers the outstanding receivables from a set of accounts to the trust and pledges to transfer future receivables generated by those accounts.

For CC-ABS, the investor's securities are "over-collateralized" - i.e., the amount of receivables in the trust exceeds the principal amount of the securities issued to the investors. For example, if $\$ 100$ million of investor securities are issued, the bank might initially sell $\$ 120$ million in receivables to the trust. In this example, the investor's interest in the pool is $\$ 100$ million and the seller's interest is $\$ 20$ million. The seller's interest is typically reported on its balance sheet as loans held by the originating bank with the associated capital requirement, while the investor's interest in the pool is removed from the balance sheet and, under current capital rules, is not subject to minimum regulatory capital requirements. $^{76}$

CC-ABS deals are typically structured so that they have multiple rated classes of bonds. The claims of lower-rated bonds are subordinated to those of higher-rated bonds. Increasing the size of the lower-rated portions enhances the credit quality of the senior classes. The least senior claim in CC-ABS deals is called the residual interest. This piece is typically retained by the bank, and its value fluctuates as the performance of the trust varies.

CC-ABS typically have two distinct cash flow periods: the revolving period and the controlled accumulation or principal-amortization period. This structure is designed to generate securities with longer maturities than the 5- to 10-month average life of a credit card receivable. The revolving period

\footnotetext{
${ }^{75}$ This discussion draws from Furletti (2002).
} 


\section{Appendix 1, The Mechanics of CC-ABS, con't.}

typically lasts 18 to 48 months (see Davidson, et al., Securitization: Structuring and Investment Analysis, 2003) but has lasted up to 11 years (see Dean, et al., The ABCs of Credit Card ABS, Fitch IBCA,1998).

During the revolving period, investors receive only interest payments (which come from finance charge payments on the receivables). Principal collections on the receivables are used to purchase new receivables generated on the accounts within the trust or to purchase a portion of the seller's interest if there are no new receivables. This causes the seller's interest to fluctuate. However, the seller is obligated to maintain a certain level of over-collateralization and must place additional accounts in the trust if necessary to maintain an adequate size of the pool. ${ }^{77}$

As the securities near maturity, CC-ABS enter into the controlled accumulation phase wherein principal collections are no longer reinvested but are paid out to the investors in equal payments until the maturity date or collected into an escrow fund and paid to investors in a lump sum at the maturity date. The controlled accumulation period usually lasts 12 months (Dean, et al., Fitch IBCA, 1998).

If the securitization follows the usual path of a revolving period followed by a controlled amortization period, the seller absorbs all credit losses. The seller owns the residual interest, which is the residual income earned by the trust in the form of excess spread. Excess spread is the income from receivables after accounting for servicing fees, interest payments to ABS bondholders, and credit losses. If the excess spread is positive, as is the norm, then increases in credit losses reduce the income paid by the trust to the bank.

Not all of the costs of maintaining the receivables pool are borne by the trust. For example, costs associated with replacing terminated or dormant accounts - an activity that is critical to maintaining the required minimum level of receivables in the trust - are absorbed by the issuing bank. In general, a bank

\footnotetext{
${ }^{76}$ While most banks report the seller's interest as loans, some banks report it as securities. While this will affect the bank's reported on-balance-sheet credit card loans, the regulatory capital requirement is unchanged.

${ }^{77}$ The bank typically has discretion over the timing of these. However, an early amortization would be triggered if the seller failed to maintain adequate over-collateralization of the trust.
} 


\section{Appendix 1, The Mechanics of CC-ABS, con't.}

will begin losing money at some excess spread that is above zero even though the trust itself may be showing a profit.

If performance deteriorates substantially and income from the pool is insufficient to make interest payments on the securities, then investors are protected from loss by various forms of credit enhancements provided by the seller. One common form of credit enhancement is the "trapping" of excess spread. When excess spread falls below a deal-specific trapping point, it is held in escrow by the trust and becomes a cash fund available to protect investors from loss. In addition, CC-ABS deals typically require sellers to finance a cash collateral account that can be used to make interest payments on securities if necessary. Credit enhancements can take other forms as well, including credit insurance and increasing the size of the residual interest.

If losses are larger and sustained, then CC-ABS contain early amortization provisions as an additional layer of protection for investors. When credit performance is extremely poor, early amortization accelerates principal payments to investors before investors absorb the losses. The credit enhancements virtually insure investors against losses in the absence of early amortization.

CC-ABS deals typically contain multiple early amortization "trigger events," including an early amortization trigger when excess spread is negative for three consecutive months. In an early amortization, all future principal payments made by the credit card customers on the securitized receivables are allocated disproportionately to the investors. In addition, new draws on existing accounts or from newly acquired accounts are funded entirely by the bank. Thus, the seller's relative share in the pool rises, and the seller is exposed to the bulk of the credit risk. The overall effect of this structural feature is that, in economic substance, the seller's interest in the securitized pool is at least partially subordinated to the investor's interest. This is one reason major credit rating agencies generally presume that the seller continues to be exposed to the risk of the securitized credit card receivables, as noted in the main body of this paper. 


\section{Appendix 1, The Mechanics of CC-ABS, con't.}

In sum, sellers absorb a large share of the credit risk even after securitizing credit card receivables. If there is no early amortization, the seller absorbs all losses in the CC-ABS through reductions in fee income and the payout of credit enhancements when excess spread is negative. In the unlikely event of an early amortization, investor exposure to credit losses is further reduced by accelerating the payment of principal to investors and the continued funding of new draws by the bank.

Finally, we note that CC-ABS transactions are engineered to obtain the accounting standards' "true sale" status required to remove assets from the originating bank's balance sheet. To obtain true sale status, the CC-ABS structure may not contain provisions that make the originating bank responsible for the subsequent performance of the collateral. In other words, the sale must be without explicit recourse. Some analysts have argued that banks have a strong incentive to provide implicit recourse (i.e., provide credit protection beyond contractual obligations) rather than allow investors to absorb losses. (See Calomiris and Mason (2003) and Higgins and Mason (2004).) Gorton and Souleles (2004) present empirical evidence that the price of CC-ABS reflects the market's expectation that banks will provide recourse rather than allow investors in CC-ABS to suffer losses. 


\section{Appendix 2: Merger-Adjusted Regressions}

Table a: Equity Capital Ratio Regressions Merger-Adjusted)

Model 1

Model 2

Model 3

\begin{tabular}{|c|c|c|c|c|c|c|}
\hline \multirow{2}{*}{$\begin{array}{l}\text { Dependent Variable } \\
\text { Independent Variables }\end{array}$} & \multicolumn{2}{|c|}{$\begin{array}{c}\text { Equity Capital to } \\
\text { Total Assets }\end{array}$} & \multicolumn{2}{|c|}{$\begin{array}{l}\text { Equity Capital to } \\
\text { Managed Assets }\end{array}$} & \multicolumn{2}{|c|}{$\begin{array}{c}\text { Equity Capital to } \\
\text { Risk-Weighted } \\
\text { Assets }\end{array}$} \\
\hline & & & & & & \\
\hline Intercept & $\begin{array}{c}0.09284 \\
(0.00199)\end{array}$ & $* * *$ & $\begin{array}{c}0.09259 \\
(0.00195)\end{array}$ & $* * *$ & $\begin{array}{c}0.1233 \\
(0.00257)\end{array}$ & *** \\
\hline Coefficient of Variation in ROE & $\begin{array}{l}-0.000435 \\
(0.000101)\end{array}$ & $* * *$ & $\begin{array}{l}-0.000439 \\
(0.000097)\end{array}$ & $* * *$ & $\begin{array}{l}-0.000540 \\
(0.000146)\end{array}$ & $* * *$ \\
\hline Total Assets & $\begin{array}{l}-0.000236 \\
(0.000114)\end{array}$ & $* *$ & $\begin{array}{l}-0.000214 \\
(0.000110)\end{array}$ & $* *$ & $\begin{array}{l}-0.000376 \\
(0.000152)\end{array}$ & $* *$ \\
\hline Total Assets Squared & $\begin{array}{c}0.000000655 \\
(0.000000340)\end{array}$ & $*$ & $\begin{array}{r}0.000000574 \\
(0.000000324\end{array}$ & $*$ & $\begin{array}{c}0.00000107 \\
(0.000000459)\end{array}$ & $* *$ \\
\hline Growth in Total Assets & $\begin{array}{c}0.00505 \\
(0.00245)\end{array}$ & $* *$ & $\begin{array}{c}0.00510 \\
(0.00240)\end{array}$ & $* *$ & $\begin{array}{c}0.00345 \\
(0.00251)\end{array}$ & \\
\hline Growth in Total Assets Squared & $\begin{array}{r}-0.0000231 \\
(0.000011)\end{array}$ & $* *$ & $\begin{array}{c}-0.0000234 \\
(0.000011)\end{array}$ & $* *$ & $\begin{array}{l}-0.0000156 \\
(0.000011)\end{array}$ & \\
\hline Credit Card Bank Indicator & $\begin{array}{r}0.09556 \\
(0.0173) \\
\end{array}$ & $* * *$ & $\begin{array}{r}0.00849 \\
(0.0128) \\
\end{array}$ & & $\begin{array}{r}0.06194 \\
(0.0167) \\
\end{array}$ & $* * *$ \\
\hline
\end{tabular}

$\begin{array}{llrr}\text { Adjusted R } \mathrm{R}^{2} & 0.3544 & 0.0429 & 0.1118\end{array}$

Number of Observations $\quad 275 \quad 275 \quad 275$

Standard errors are in parentheses. The standard errors are heteroscedasticity-consistent and calculated using the Davidson and MacKinnon (1993) adjustment of the covariance matrix of the estimated parameters, $\left(X^{\prime} X\right)^{-1}\left(X^{\prime} \hat{\Omega} X\right)\left(X^{\prime} X\right)^{-1}$ where $\hat{\Omega} \equiv \operatorname{diagonal}$ matrix with $\frac{n}{n-k} e_{t}^{2}$ on the diagonal, where $e_{t}$ is the estimated regression error, that is, $e_{t}=y_{t}-x_{t} \hat{\beta}, n=$ number of observations and $k=$ number of explanatory variables.

$* * *$ Significantly different from zero at the $99 \%$ level, $* *$ Significantly different from zero at the $95 \%$ level, $*$ Significantly different from zero at the $90 \%$ level.

Equity capital to assets is equity capital/total assets as of June 2004, where equity capital is RCFD3210 from the Call Report and total assets is RCFD2170 from the Call Report.

Equity capital to managed assets is equity capital/managed assets, where managed assets equals total assets plus outstanding credit card assets sold and securitized with servicing retained or with recourse or other seller-provided credit enhancements minus seller's interest in credit card securitizations held on balance sheet as loans or securities as of June 2004.

Equity capital to risk-weighted assets is equity capital/risk-weighted assets (RCFDA223 from the Call Report) as of June 2004.

Data on the coefficient of variation in ROE and asset growth are adjusted for bank mergers. Mergers are accounted for in the year in which they took place (e.g., if two banks merged in 2002, the merger was accounted for in 2002 but not in prior years).

Growth in total assets is growth in total assets between year-end 2000 and year-end 2003, where total assets in 2000 has been merger-adjusted. That is, growth in total assets $=$ [total assets in 2003 of surviving bank/ (total assets in 2000 of surviving bank + total assets in 2000 of targets) ]-1, where targets are any banks acquired by the surviving bank in 2001, 2002, or 2003. (Assets in this calculation are unweighted by risk (RCFD2170 from the Call Report).)

The coefficient of variation in ROE is the standard deviation of ROE divided by mean of ROE from 1992-2003, where ROE in year $t$ is calculated as income in year $t$ divided by [(equity in year $t+$ equity in year $t-1) / 2$ ], where equity in year $t-1$ is the sum of the surviving bank's equity and the equity of all of the banks it acquired in year $t$.

Total assets are total assets, unweighted by risk (RCFD2170 from the Call Report), measured in units of \$1 billion as of June 2004.

Credit card bank indicator is equal to 1 if the bank is a credit card specialty bank, or 0 otherwise. There are 13 credit card specialty banks in the sample. 
Appendix 2: Merger-Adjusted Regressions, con't.

\section{Table b: Total Capital Ratio Regressions Merger-Adjusted)}

Model 1

Total Capital to Total Assets
Model 2

Total Capital to Managed Assets
Model 3

\begin{tabular}{|c|c|c|c|c|c|c|}
\hline Dependent Variable & \multicolumn{2}{|c|}{$\begin{array}{c}\text { Total Capital to } \\
\text { Total Assets } \\
\end{array}$} & \multicolumn{2}{|c|}{$\begin{array}{l}\text { Total Capital to } \\
\text { Managed Assets }\end{array}$} & \multicolumn{2}{|c|}{$\begin{array}{c}\text { Total Capital to } \\
\text { Risk-Weighted Assets }\end{array}$} \\
\hline \multicolumn{7}{|l|}{ Independent Variables } \\
\hline \multirow[t]{2}{*}{ Intercept } & 0.09190 & $* * *$ & 0.09174 & $* * *$ & 0.1217 & $* * *$ \\
\hline & $(0.00148)$ & & $(0.00149)$ & & $(0.00184)$ & \\
\hline \multirow[t]{2}{*}{ Coefficient of Variation in ROE } & -0.000429 & $* * *$ & -0.000431 & $* * *$ & -0.000517 & $* * *$ \\
\hline & $(0.000014)$ & & $(0.000017)$ & & $(0.000035)$ & \\
\hline \multirow[t]{2}{*}{ Total Assets } & -0.0000663 & & -0.0000682 & & -0.000219 & $* * *$ \\
\hline & $(0.000093)$ & & $(0.000108)$ & & $(0.000084)$ & \\
\hline \multirow[t]{2}{*}{ Total Assets Squared } & 0.00000014 & & 0.00000013 & & 0.000000611 & $* *$ \\
\hline & $(0.00000028$ & & $(0.00000033$ & & $(0.000000270)$ & \\
\hline \multirow[t]{2}{*}{ Growth in Total Assets } & 0.00389 & $* *$ & 0.00404 & $* *$ & 0.00206 & \\
\hline & $(0.00194)$ & & $(0.00184)$ & & $(0.00199)$ & \\
\hline \multirow[t]{2}{*}{ Growth in Total Assets Squared } & -0.0000179 & $* *$ & -0.0000186 & $* *$ & -0.00000927 & \\
\hline & $(0.00000878$ & & $(0.00000834$ & & $(0.00000903)$ & \\
\hline \multirow[t]{2}{*}{ Credit Card Bank Indicator } & 0.1004 & $* * *$ & 0.01451 & & 0.06711 & $* * *$ \\
\hline & $(0.0144)$ & & $(0.0171)$ & & $(0.0136)$ & \\
\hline
\end{tabular}

$\begin{array}{lrrr}\text { Adjusted } \mathrm{R}^{2} & 0.5447 & 0.0554 & 0.2705 \\ \text { Number of Observations } & 275 & 275 & 275\end{array}$

Standard errors are in parentheses. The standard errors are heteroscedasticity-consistent and calculated using the Davidson and MacKinnon (1993) adjustment of the covariance matrix of the estimated parameters, $\left(X^{\prime} X\right)^{-1}\left(X^{\prime} \hat{\Omega} X\right)\left(X^{\prime} X\right)^{-1}$ where $\hat{\Omega} \equiv$ diagonal matrix with $\frac{n}{n-k} e_{t}^{2}$ on the diagonal, where $e_{t}$ is the estimated regression error, that is, $e_{t}=y_{t}-x_{t} \hat{\beta}, n=$ number of observations and $k=$ number of explanatory variables.

*** Significantly different from zero at the $99 \%$ level, $* *$ Significantly different from zero at the $95 \%$ level, * Significantly different from zero at the $90 \%$ level.

Total capital to assets is total risk-based capital/total assets as of June 2004, where total risk-based capital is RCFD3792 from the Call Report and total assets is RCFD2170 from the Call Report.

Total capital to managed assets is total capital/managed assets, where managed assets equals total assets plus outstanding credit card assets sold and securitized with servicing retained or with recourse or other seller-provided credit enhancements as of June 2004.

Total capital to risk-weighted assets is total capital/risk-weighted assets (RCFDA223 from the Call Report) as of June 2004.

Data on the coefficient of variation in ROE and asset growth are adjusted for bank mergers. Mergers are accounted for in the year in which they took place (e.g., if two banks merged in 2002, the merger was accounted for in 2002 but not in prior years).

Growth in total assets is growth in total assets between year-end 2000 and year-end 2003, where total assets in 2000 has been merger-adjusted. That is, growth in total assets $=$ [total assets in 2003 of surviving bank/ (total assets in 2000 of surviving bank + total assets in 2000 of targets)] -1 , where targets are any banks acquired by the surviving bank in 2001, 2002, or 2003. (Assets in this calculation are unweighted by risk (RCFD2170 from the Call Report).)

The coefficient of variation in ROE is the standard deviation of ROE divided by mean of ROE from 1992-2003, where ROE in year $t$ is calculated as income in year $t$ divided by [(equity in year $t+$ equity in year $t-1) / 2$ ], where equity in year $t-1$ is the sum of the surviving bank's equity and the equity of all of the banks it acquired in year $t$.

Total assets are total assets, unweighted by risk (RCFD2170 from the Call Report), measured in units of \$1 billion as of June 2004.

Credit card bank indicator is equal to 1 if the bank is a credit card specialty bank, or 0 otherwise. There are 13 credit card specialty banks in the sample. 


\section{Appendix 2: Merger-Adjusted Regressions, con't.}

\section{Table c: Tier 1 Capital Ratio Regressions Merger-Adjusted)}

Model 1

\begin{tabular}{|c|c|c|c|c|c|c|}
\hline $\begin{array}{l}\text { Dependent Variable } \\
\text { Independent Variables }\end{array}$ & \multicolumn{2}{|c|}{$\begin{array}{c}\text { Tier } 1 \text { Capital to } \\
\text { Total Assets } \\
\end{array}$} & \multicolumn{2}{|c|}{$\begin{array}{l}\text { Tier } 1 \text { Capital to } \\
\text { Managed Assets }\end{array}$} & \multicolumn{2}{|c|}{$\begin{array}{c}\text { Tier 1 Capital to } \\
\text { Risk-Weighted } \\
\text { Assets } \\
\end{array}$} \\
\hline \multirow[t]{2}{*}{ Intercept } & 0.08117 & $* * *$ & 0.08094 & $* * *$ & 0.1075 & $* * *$ \\
\hline & $(0.00142)$ & & $(0.00139)$ & & $(0.00186)$ & \\
\hline \multirow[t]{2}{*}{ Coefficient of Variation in $\mathrm{ROE}$} & -0.000417 & $* * *$ & -0.000420 & $* * *$ & -0.000510 & $* * *$ \\
\hline & $(0.000014)$ & & $(0.000016)$ & & $(0.000031)$ & \\
\hline \multirow[t]{2}{*}{ Total Assets } & -0.000340 & $* * *$ & -0.000326 & $* * *$ & -0.000517 & $* * *$ \\
\hline & $(0.000080)$ & & $(0.000081)$ & & $(0.000093)$ & \\
\hline \multirow[t]{2}{*}{ Total Assets Squared } & 0.000000881 & $* * *$ & 0.000000824 & $* * *$ & 0.00000138 & $* * *$ \\
\hline & $(0.000000260)$ & & $(0.000000257)$ & & $(0.000000307)$ & \\
\hline \multirow[t]{2}{*}{ Growth in Total Assets } & 0.00401 & $* *$ & 0.00415 & $* *$ & 0.00242 & \\
\hline & $(0.00183)$ & & $(0.00173)$ & & $(0.00191)$ & \\
\hline \multirow[t]{2}{*}{ Growth in Total Assets Squared } & -0.00001813 & $* *$ & -0.0000188 & $* *$ & -0.0000105 & \\
\hline & $(0.00000831)$ & & $(0.00000785)$ & & $(0.00000863)$ & \\
\hline \multirow[t]{2}{*}{ Credit Card Bank Indicator } & 0.08142 & $* * *$ & 0.00920 & & 0.05327 & $* * *$ \\
\hline & $(0.0119)$ & & $(0.0118)$ & & $(0.0107)$ & \\
\hline Adjusted $\mathrm{R}^{2}$ & 0.4779 & & 0.1111 & & 0.2230 & \\
\hline Number of Observations & 275 & & 275 & & 275 & \\
\hline
\end{tabular}

Standard errors are in parentheses. The standard errors are heteroscedasticity-consistent and calculated using the Davidson and MacKinnon (1993) adjustment of the covariance matrix of the estimated parameters, $\left(X^{\prime} X\right)^{-1}\left(X^{\prime} \hat{\Omega} X\right)\left(X^{\prime} X\right)^{-1}$ where $\hat{\Omega} \equiv$ diagonal matrix with $\frac{n}{n-k} e_{t}^{2}$ on the diagonal, where $e_{t}$ is the estimated regression error, that is, $e_{t}=y_{t}-x_{t} \hat{\beta}, n=$ number of observations and $k=$ number of explanatory variables.

$* * *$ Significantly different from zero at the $99 \%$ level, $* *$ Significantly different from zero at the $95 \%$ level, $*$ Significantly different from zero at the $90 \%$ level.

Tier 1 capital to assets is tier 1 capital/total assets as of June 2004, where tier 1 capital is RCFD8274 from the Call Report and total assets is RCFD2170 from the Call Report.

Tier 1 capital to managed assets is tier 1 capital/managed assets, where managed assets equals total assets plus outstanding credit card assets sold and securitized with servicing retained or with recourse or other seller-provided credit enhancements as of June 2004.

Tier 1 capital to risk-weighted assets is tier 1 capital/risk-weighted assets (RCFDA223 from the Call Report) as of June 2004.

Data on the coefficient of variation in ROE and asset growth are adjusted for bank mergers. Mergers are accounted for in the year in which they took place (e.g., if two banks merged in 2002, the merger was accounted for in 2002 but not in prior years).

Growth in total assets is growth in total assets between year-end 2000 and year-end 2003, where total assets in 2000 has been merger-adjusted. That is, growth in total assets = [total assets in 2003 of surviving bank / (total assets in 2000 of surviving bank + total assets in 2000 of targets) ]-1, where targets are any banks acquired by the surviving bank in 2001, 2002, or 2003. (Assets in this calculation are unweighted by risk (RCFD2170 from the Call Report).)

The coefficient of variation in ROE is the standard deviation of ROE divided by the mean of ROE from 1992-2003, where ROE in year $\mathrm{t}$ is calculated as income in year $t$ divided by [(equity in year $t+$ equity in year $t-1) / 2$ ], where equity in year $t-1$ is the sum of the surviving banks' equity and the equity of all of the banks it acquired in year $t$.

Total assets are total assets, unweighted by risk (RCFD2170 from the Call Report), measured in units of \$1 billion as of June 2004.

Credit card bank indicator is equal to 1 if the bank is a credit card specialty bank, or 0 otherwise. There are 13 credit card specialty banks in the sample. 


\section{Appendix 3: Calculating the Change in Minimum Capital Requirements from a Shift from Basel I to Basel II}

\section{Total Capital Requirements}

Let $\mathrm{k}_{\mathrm{I}}=\mathrm{T}_{\mathrm{I}}-\mathrm{D}_{\mathrm{I}}+\mathrm{R}_{\mathrm{IE}}=0.08 \times \mathrm{RWA}_{\mathrm{I}}=$ Basel I total risk-based capital requirement, and

$$
\begin{gathered}
\mathrm{k}_{\mathrm{II}}=\mathrm{T}_{\mathrm{II}}-\mathrm{D}_{\mathrm{II}}+\left[\mathrm{R}_{\mathrm{IIE}}-\mathrm{EL}\right]=0.08 \times \mathrm{RWA}_{\mathrm{II}}=\text { Basel II total risk-based capital requirement, } \\
\text { where subscripts } i=\text { I and II refer to Basel I and Basel II, respectively, and } \\
\qquad \begin{array}{ll}
\mathrm{T}_{\mathrm{i}} & =\text { total regulatory capital excluding reserves, } \\
\mathrm{D}_{\mathrm{i}} & =\text { deductions from capital for residual interests in CC-ABS, }{ }^{78} \\
\mathrm{R}_{\mathrm{EE}} & =\text { reserves (i.e., allowance for loan and lease losses), } \\
\mathrm{RWA}_{\mathrm{i}} & =\text { risk-weighted assets, } \\
\mathrm{EL} & =\text { estimated expected losses under Basel II. }
\end{array}
\end{gathered}
$$

Rearranging the Basel I and Basel II capital equations and solving for $\left(\mathrm{T}_{\mathrm{I}}+\mathrm{R}_{\mathrm{IE}}\right)$ and $\left(\mathrm{T}_{\mathrm{II}}+\mathrm{R}_{\mathrm{IIE}}\right)$, respectively, yields:

$$
\begin{aligned}
& \mathrm{T}_{\mathrm{I}}+\mathrm{R}_{\mathrm{IE}}=\left(0.08 \times \mathrm{RWA}_{\mathrm{I}}\right)+\mathrm{D}_{\mathrm{I}} \\
& \mathrm{T}_{\mathrm{II}}+\mathrm{R}_{\mathrm{IIE}}=\left(0.08 \times \mathrm{RWA}_{\mathrm{II}}\right)+\mathrm{EL}+\mathrm{D}_{\mathrm{II}}
\end{aligned}
$$

These equations allow us to compare the regulatory capital and reserves under Basel I and Basel II. Note that these are requirements gross of deductions and for both unexpected and expected losses. Thus, they put the Basel I and Basel II requirements on a comparable basis.

Equation (A2) allows us to analyze the components of the Basel II total capital requirement discussed in Section V.B1 of the paper.

If the credit conversion factor (CCF) for the investor's interest in securitized credit card receivables is zero, then the Basel II capital requirement comprises:

$0.08 \times \mathrm{RWA}_{\mathrm{II}}=$ estimated UL from on-balance-sheet outstanding balances and the UL associated with undrawn lines of credit from those balances,

EL = capital deductions for expected losses from on-balance-sheet outstanding balances and the EL associated with undrawn lines of credit from those balances,

$\mathrm{D}_{\mathrm{II}} \quad=$ other capital deductions, which for credit card portfolios are principally residual interests associated with securitizations

The effective capital requirement depends on how much of a bank's actual reserves are credited against

\footnotetext{
${ }^{78}$ We treat residual interests in securitizations as deductions from total capital when calculating Basel I and Basel II capital requirements, even though these assets are technically included in risk-weighted assets for Basel I and deducted from capital under Basel II. This is appropriate since the minimum capital requirement under Basel I increases dollar-for-dollar with the amount of these residual interests.
} 
capital $\left(\mathrm{R}_{\mathrm{IIE}}\right)^{79}$

If the CCF for the investor's interest in CC-ABS is positive, then there are additions to both $\mathrm{RWA}_{\mathrm{II}}$ and EL under the Basel II minimum capital requirement.

The dollar change in required capital minimums resulting from a shift from Basel I to Basel II-based rules is measured as, $\left(T_{I I}+R_{I E}\right)-\left(T_{I}+R_{I E}\right)$, which by equations $A 1$ and $A 2$ is:

$$
\left(\mathrm{T}_{\mathrm{II}}+\mathrm{R}_{\mathrm{IIE}}\right)-\left(\mathrm{T}_{\mathrm{I}}+\mathrm{R}_{\mathrm{IE}}\right)=\left(\mathrm{T}_{\mathrm{II}}-\mathrm{T}_{1}\right)+\left(\mathrm{R}_{\mathrm{IIE}}-\mathrm{R}_{\mathrm{IE}}\right)=\left[0.08 \times\left(\mathrm{RWA}_{\mathrm{II}}-\mathrm{RWA}_{\mathrm{I}}\right)\right]+\mathrm{EL}+\left(\mathrm{D}_{\mathrm{II}}-\mathrm{D}_{\mathrm{I}}\right)
$$

Thus, the percentage change in required capital minimums resulting from a shift from Basel I- to Basel IIbased rules is:

[(Change in required capital minimum resulting from a shift from Basel I-based to Basel II-based rules / Basel I capital requirement gross of deductions) -1$] \times 100$

$$
\left.=\left\{\left[\left[0.08 \times\left(\mathrm{RWA}_{\mathrm{II}}-\mathrm{RWA}_{\mathrm{I}}\right)\right]+\mathrm{EL}+\left(\mathrm{D}_{\mathrm{II}}-\mathrm{D}_{\mathrm{I}}\right)\right] /\left(\mathrm{T}_{\mathrm{I}}+\mathrm{R}_{\mathrm{IE}}\right)\right]-1\right\} \times 100 .
$$

\section{Tier 1 Capital Requirements}

Let $\mathrm{k}_{\mathrm{I}}{ }^{1}=\mathrm{T}_{\mathrm{I}}{ }^{1}-\mathrm{D}_{\mathrm{I}}{ }^{1}=0.04 \times \mathrm{RWA}_{\mathrm{I}}=$ Basel I tier 1 risk-based capital requirement, and

$$
\mathrm{k}_{\mathrm{II}}^{1}=\mathrm{T}_{\mathrm{II}}^{1}-\mathrm{D}_{\mathrm{II}}{ }^{1}-\left(0.5 \times \min \left[0, \mathrm{EL}-\mathrm{R}_{\mathrm{IIE}}\right]\right)=0.04 \times \mathrm{RWA}_{\mathrm{II}}=\underset{\text { requirement, }}{\text { Basel II tier } 1 \text { risk-based capital }}
$$

where the variables are the same as the section above, with the superscript 1 referring to the tier 1 value of the variable.

Rearranging the Basel I and Basel II equations and solving for $T_{I}$ and $T_{I I}$, respectively, yields:

$$
\begin{aligned}
& \mathrm{T}_{\mathrm{I}}^{1}=\left(0.04 \times \mathrm{RWA}_{\mathrm{I}}\right)+\mathrm{D}_{\mathrm{I}}^{1} \\
& \mathrm{~T}_{\mathrm{II}}{ }^{1}=\left(0.04 \times \mathrm{RWA}_{\mathrm{II}}\right)+\mathrm{D}_{\mathrm{II}}{ }^{1}+\left(0.5 \times \min \left[0, \mathrm{EL}-\mathrm{R}_{\mathrm{IIE}}\right]\right) .
\end{aligned}
$$

The three terms on the right-hand side of equation (A4) are the components of the Basel II tier 1 capital requirement discussed in section V.B2 of the paper.

If the CCF for the investor's interest in $\mathrm{CC}-\mathrm{ABS}$ is zero, then the tier 1 requirement comprises:

\footnotetext{
${ }^{79}$ For this purpose, we assume that actual reserves are maintained at the same levels under Basel II as under the Basel I-based rules.
} 


$$
\begin{aligned}
0.04 \times \mathrm{RWA}_{\mathrm{II}}= & \text { estimated UL from on-balance-sheet outstanding balances and the UL } \\
& \text { associated with undrawn lines of credit from those balances, } \\
= & \text { tier } 1 \text { deductions for gain-on-sale associated with CC-ABS, }{ }^{80} \\
\mathrm{D}_{\mathrm{II}}{ }^{1} & \\
0.5 \times \min \left[0, \mathrm{EL}-\mathrm{R}_{\mathrm{IIE}}\right]= & \text { Basel II } 50 \text { percent deduction from tier } 1 \text { for any excess of EL } \\
& \text { over eligible reserves. }
\end{aligned}
$$

The effective tier 1 capital requirement under Basel II depends on how much of a bank's actual reserves are credited against capital $\left(\mathrm{R}_{\mathrm{IIE}}\right)$.

If the CCF for the investor's interest in CC-ABS is positive, then there are additions to both $\mathrm{RWA}_{\mathrm{II}}$ and EL under the Basel II minimum capital requirement.

The dollar change in tier 1 required capital minimums resulting from a shift from Basel I-based to Basel II-based rules is measured as $\mathrm{T}_{\mathrm{II}}{ }^{1}-\mathrm{T}_{\mathrm{I}}{ }^{1}$, which by equations $\mathrm{A} 3$ and $\mathrm{A} 4$ is:

$$
\left(\mathrm{T}_{\mathrm{II}}{ }^{1}-\mathrm{T}_{\mathrm{I}}{ }^{1}\right)+=\left[0.04 \times\left(\mathrm{RWA}_{\mathrm{II}}{ }^{1}-\mathrm{RWA}_{\mathrm{I}}{ }^{1}\right)\right]+\left(\mathrm{D}_{\mathrm{II}}{ }^{1}-\mathrm{D}_{\mathrm{I}}{ }^{1}\right)+\left(0.5 \times \min \left[0, \mathrm{EL}-\mathrm{R}_{\mathrm{IIE}}\right]\right) .
$$

Thus, the percentage change in tier 1 required capital minimum resulting from a shift from Basel I-based to Basel II-based rules is:

[(Change in tier 1 required capital minimum resulting from a shift from Basel I-based to Basel IIbased rules/Basel I tier 1 capital requirement gross of deductions) -1$] \times 100$

$$
\begin{aligned}
=\left\{\left[\left\{\left[0.04 \times\left(\mathrm{RWA}_{\mathrm{II}}{ }^{1}-\mathrm{RWA}_{\mathrm{I}}{ }^{1}\right)\right]+\left(\mathrm{D}_{\mathrm{II}}{ }^{1}-\mathrm{D}_{\mathrm{I}}{ }^{1}\right)+\left(0.5 \times \min \left[0, \mathrm{EL}-\mathrm{R}_{\mathrm{IIE}}\right]\right)\right] /\right.\right. \\
\\
\left.\left.\left(0.04 \times \mathrm{RWA}_{\mathrm{I}}\right)+\mathrm{D}_{\mathrm{I}}{ }^{1}\right]-1\right\} \times 100 .
\end{aligned}
$$

\footnotetext{
${ }^{80}$ Under Basel I this deduction would typically be taken half from tier 1 and half from tier 2 capital.
} 


\section{References}

“Advance Notice of Proposed Rulemaking: Risk-Based Capital Guidelines and Implementation of New Basel Capital Accord." Federal Reserve Board (August 4, 2003). http://www.federalreserve.gov/boarddocs/press/bcreg/2003/20030804/attachment.pdf.

Calem, Paul S., and Rafael Rob (1999). "The Impact of Capital-Based Regulation on Bank Risk-Taking." Journal of Financial Intermediation 8: 317-352.

Calomiris, Charles W., and Joseph R. Mason (2003). "Credit Card Securitization and Regulatory Arbitrage.” Federal Reserve Bank of Philadelphia Working Paper 03-7.

Carlson, Mark, and Roberto Perli (2004). "Profits and Balance Sheet Developments at U.S. Commercial Banks in 2004." Federal Reserve Bulletin (Spring 2004), pp. 162-191.

Chakravorti, Sujit, and William R. Emmons (2001). "Who Pays for Credit Cards?" Federal Reserve Bank of Chicago Emerging Payments Occasional Paper Series 2001-1.

Davidson, Andrew, Anthony B. Saunders, Lan-Ling Wolff, and Anne Ching (2003). Securitization: Structuring and Investment Analysis. Hoboken, NJ: John Wiley and Sons, Inc.

Davidson, Russell, and James G. MacKinnon, (1993) Estimation and Inference in Econometrics, New York: Oxford University Press.

Dean, Michael R., Chris Mrazek, Richard C. Drason, Mark Sun, Kathy Moon, and Michelle Galvez (1998). "The ABCs of Credit Card ABS." http://www.fitchratings.com/corporate/reports/ report.cfm?rpt_id=34636\&sector_flag $=1 \&$ marketsector $=2 \&$ detail $=$.

deFontnouvelle, Patrick (2004). "The Competitive Effects of Operation Risk Capital Requirements." Federal Reserve Bank of Boston.

Diamond, Douglas, and Raghuram Rajan (2000). “A Theory of Bank Capital.” Journal of Finance 55, pp. 2432-2465.

Federal Deposit Insurance Corporation (2004). "Bank Closing Information for NextBank, N.A. Phoenix, AZ." http://www.fdic.gov/bank/individual/failed/nextbank.html.

Furletti, Mark (2002). “An Overview of Credit Card Asset-Backed Securities.” Federal Reserve Bank of Philadelphia Payment Cards Center Discussion Paper.

Gorton, Gary, and Nicholas Souleles (2004). "Special Purpose Vehicles and Securitization." University of Pennsylvania Working Paper, Philadelphia.

Greenspan, Alan (2005). "Bank Regulation," Remarks before the Independent Community Bankers of America National Convention, San Antonio, Texas (via videoconference), March 11, 2005 (www.federalreserve.gov/boarddocs/speeches/2005/20050311/default.htm).

Havlicek, Barbara, Brian M. Clarkson, Farisa Zarin et al. (2002). "Securitization and Its Effect on the Credit Strength of Companies: Moody’s Perspective 1987-2002.” 
http://www.moodys.com/moodys/cust/research/venus/Publication/Special\%20Comment/noncateg orized_number/74455.pdf.

Higgins, Eric J., and Joseph R. Mason (2004). "What Is the Value of Recourse to Asset-Backed Securities? A Clinical Study of Credit Card Banks.” Journal of Banking and Finance 28 (4): 857-874.

"Internal Ratings-Based Systems for Retail Credit Risk for Regulatory Capital." Federal Register 69, no. 207 (October 27, 2004): 62747-62776.

Milligan, Jack, "Who Will Choose Basel II? All Large Banks - Except the Very Biggest, Who Have No Choice-Are Thinking Hard About Opting In, Even Before the U.S. Regulators Develop Detailed Rules," ABA Banking Journal, November 1, 2004.

Olson, Kim, Deborah Seife, Michael Dean, Michael Nelson, Olivier Delfour, Sharon Haas, and John Olert (2003). "Basel II Securitization Proposals: Primer and Observations." http://www.fitchratings.com/corporate/reports/report.cfm?rpt_id=170816\&sector_flag=3\&market sector $=2 \&$ detail $=$.

Paletta, Damian, "Hints of Broader-than-Expected Basel II Adoption," American Banker, July 21, 2004. (Also, "Takers and Tire Kickers: Where 29 of the Largest Banking Companies Stand on Participation in Basel II," sidebar on the article.)

“Smaller U.S. Banks Say Basel Accord Unfair.” Reuters News, June 22, 2004.

“Substance, Not Form, of Securitizations Drives Leverage Analysis.” Credit Week, April 24, 2002.

“Will Sales Treatment Survive a Recession?” Asset Sales Report, March 31, 1997.

White (1980). "A Heteroscedasticity-Consistent Covariance Matrix Estimator and a Direct Test for Heteroscedasticity," Econometrica 48, 817-838. 